\title{
The illaenid trilobites Vysocania (Vaněk \& Vokáč, 1997) and Octillaenus (Barrande, 1846) from the Upper Ordovician of the Czech Republic, Portugal, Spain and Morocco
}

\author{
Sofia Pereira, Carlos Marques da Silva, Artur Abreu SÁ, Miguel Pires, \\ ARMANdo MARQues GUedes, Petr BudIL, LUKÁŠ LAIBL \& ISABEL RÁBANO
}

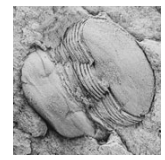

\begin{abstract}
The illaenid trilobite Vysocania is widely represented in the Upper Ordovician of the Czech Republic, Portugal and Spain, and is one of the most characteristic taxa in the high-latitude peri-Gondwana palaeobiogeographical region to which it is endemic. Three species of the genus that were formerly assigned to Stenopareia and Zetillaenus, from the Czech Republic and Spain respectively, are herein revised, and a new species is described from the Czech Republic. The genus Octillaenus, of which a new species is described from the Upper Ordovician of Morocco, is considered to have arisen from Vysocania through paedomorphic (neotenic) processes. The relationships between Vysocania, Octillaenus, Stenopareia and Zetillaenus are reviewed and the criteria used in the definition of these taxa discussed. Species assigned to Vysocania are V. vaneki (type-species), V. iberica, V. moraveci sp. nov. and V. panderi; species assigned to Octillaenus are $O$. hisingeri (type-species) and $O$. marocanus sp. nov. Vysocania appears for the first time in the lower Berounian (Sandbian) and has its last undoubted record in the upper Berounian (upper Katian); Octillaenus is presently restricted to the Kralodvorian (upper Katian). - Key words: Stenopareia, Zetillaenus, Illaenidae, high-latitude peri-Gondwana, Dalmanitoidean Realm.
\end{abstract}

Pereira, S., Marques da Silva, C., SÁ, A.A., Pires, M., Marques Guedes, A., Budil, P., Laibl, L. \& Rábano, I. 2017. The illaenid trilobites Vysocania (Vaněk \& Vokáč, 1997) and Octillaenus (Barrande, 1846) from the Upper Ordovician of the Czech Republic, Portugal, Spain and Morocco. Bulletin of Geosciences 92(4), $465-490$ (11 figures). Czech Geological Survey, Prague. ISSN 1214-1119. Manuscript received October 25, 2016; accepted in revised form November 16, 2017; published online December 18, 2017; issued December 31, 2017.

\begin{abstract}
Sofia Pereira \& Carlos Marques da Silva, Departamento de Geologia and Instituto Dom Luiz, Faculdade de Ciências, Universidade de Lisboa, 1749-016 Lisboa,Portugal; ardi_eu@hotmail.com, paleo.carlos@fc.ul.pt•Artur Abreu Sá, Departamento de Geologia, Universidade de Trás-os-Montes e Alto Douro, Quinta de Prados 5000-801 Vila Real, Portugal; asa@utad.pt•Miguel Pires, Arcodere, Unipessoal Lda., Rua da Sociedade 2, 2350-030 Torres Novas, Portugal; arcodere@gmail.com • Armando Marques Guedes, Faculdade de Direito, Universidade Nova de Lisboa, 1099-032 Lisboa, Portugal; amarquesguedes@gmail.com • Petr Budil, Czech Geological Survey, Klárov 3, Praha 1, 118 21, Czech Republic; petr.budil@geology.cz • Lukáš Laibl, National Museum Prague, Department of Palaeontology, Václavské náměstí 68, Praha 1, 115 79, Czech Republic; lukaslaibl@gmail.com・Isabel Rábano, Museo Geominero, igme, Rios Rosas 23, 28003 Madrid, Spain; i.rabano@igme.es
\end{abstract}

The smooth exoskeleton of illaenids causes considerable difficulties in taxonomic differentiation within this group (e.g. Jaanusson 1954, Lane \& Thomas 1983). Numerous Upper Ordovician illaenid species have traditionally been included in the widely conceived genus Stenopareia Holm, 1886, which has long served as a 'waste-bin taxon' to group illaenid morphologies characterized especially by nine thoracic segments, a highly convex cephalon, glabella defined by short (exsag.) axial furrows and pygidium semicircular in outline. As presently conceived, Stenopareia is a polyphy- letic taxon in need of revision using modern phylogenetic analysis. Such an analysis has proved its usefulness with closely related taxa; e.g. Bumastoides Whittington, 1954, analyzed by Carlucci et al. (2012). The need for such a revision is common to many Upper Ordovician illaenids.

During the last 70 years, reports of Stenopareia species from the high latitude peri-Gondwanan region remained taxonomically stable (e.g. Jaanusson 1954, Šnajdr 1957, Bruthansová 2003). However, crucial morphological differences distinguish these species from Baltic Stenopareia s.s. 


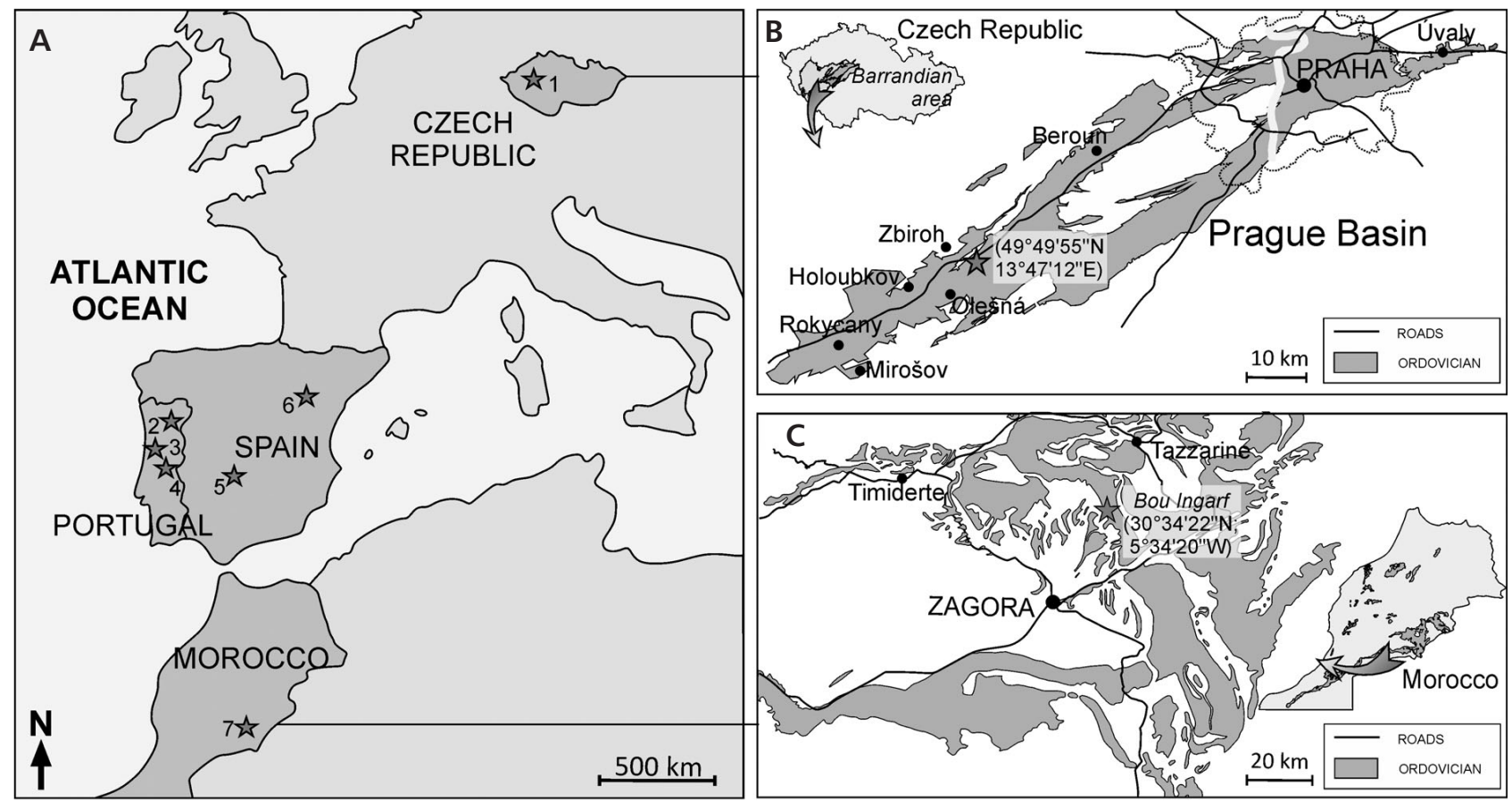

Figure 1. Geographical location of the localities (A) and type-localities for the new taxa (B, C) of Vysocania Vaněk \& Vokáč, 1997. • A - Czech Republic: 1 - Prague Basin; Portugal: 2 - Torre de Moncorvo, 3 - Buçaco-Penacova, 4 - Maçăo; Spain: 5 - Ciudad Real, 6 - Zaragoza; Morocco: 7 - Zagora. - B - detail of the Zbiroh type locality for Vysocania moraveci sp. nov. • C - detail of the Bou Ingarf type locality for Octillaenus marocanus sp. nov.

These differences, detailed in this work, justify the separation of the peri-Gondwanan species in a different genus. Vaněk \& Vokáč (1997) erected the genus Vysocania to include only Zbirovia vaneki Šnajdr, 1958, which is congeneric with the Czech species previously assigned to the genus Stenopareia. For this reason, the genus Vysocania should be used to embrace those species. On the other hand, the genus Octillaenus Salter, 1867 remained monospecific since its definition, the type species Octillaenus hisingeri (Barrande, 1846) being restricted to the upper Katian of the Czech Republic. A new species from a coeval unit of Morocco is described and it is suggested that Octillaenus developed from Vysocania through paedomorphic processes.

Vysocania is widely represented in the periGondwanan region, being one of the most characteristic trilobite genera in the Upper Ordovician sequences of the Czech Republic, Portugal and Spain (Fig. 1A). Vysocania is particularly abundant at the base of the successions bounded by ironstone horizons, in which trilobite diversity is fairly low. Octillaenus is currently known from the Czech Republic and Morocco.

\section{Geographical and geological settings of material}

Czech Republic. - Vysocania is known from several stratigraphical units (Fig. 2) and localities in the Prague Basin of the Barrandian area (locality 1, Fig. 1A; see Havlíček 1998, Fatka et al. 2013 and Kraft et al. 2015 for information on the Ordovician stratigraphy of the basin). The specimens of Vysocania moraveci sp. nov. come from the lower Berounian Libeň and Letná formations. The specimens of $V$. panderi (Barrande, 1852) originate from the middle Berounian Vinice and Zahořany formations. The base of the Vinice Formation is marked by a discontinuous ironstone ore layer named the Zdice-Nučice 'Horizon', characterized by a low diversity trilobite assemblage in which Vysocania is one of the most abundant elements. The specimens of $V$. vaneki (Šnajdr, 1958) come from the upper Berounian Bohdalec Formation, the type horizon of the species being the discontinuous, sideritic Karlík 'Ore Horizon' at the base of the formation. The specimens of Octillaenus hisingeri were collected from the mid to upper part of the Kralodvorian Králův Dvůr Formation, being particularly abundant in the so called Perník Bed (pelocarbonate), located in the uppermost part of the unit.

Portugal. - Portuguese specimens of Vysocania came from three different regions: from the Mós locality in Torre de Moncorvo Municipality of the Bragança District, in the northeastern part of the country (locality 2, Fig. 1A); from the Louredo locality in the Buçaco region of the Aveiro District, central Portugal (locality 3, Fig. 1A); and from the Pereiro locality in Mação Municipality of the Santarém District, central Portugal (locality 4, Fig. 1A). In the Torre 


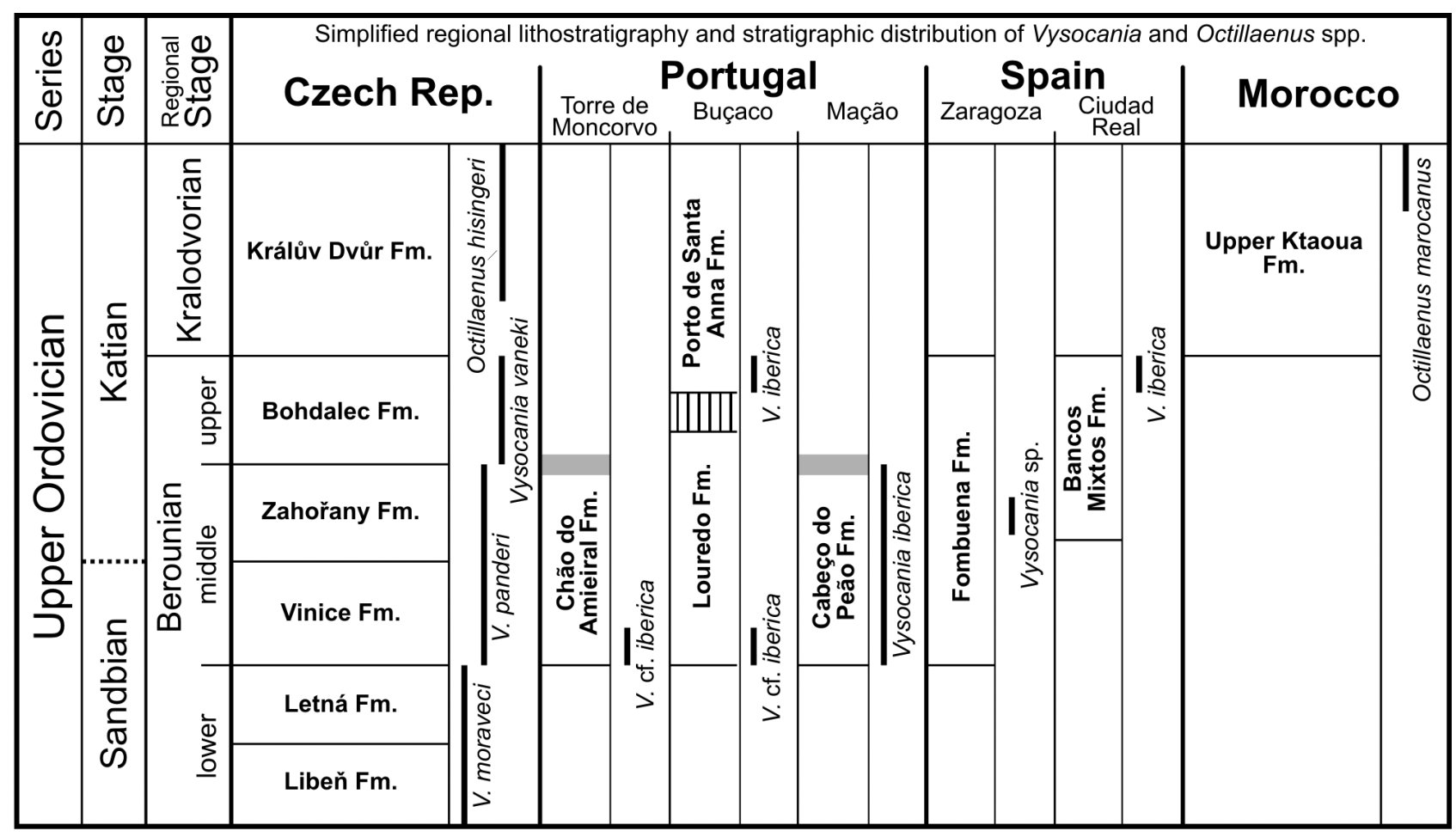

Figure 2. The chronostratigraphical, geographical and lithostratigraphical distribution of species of Vysocania Vaněk \& Vokáč, 1997. Regional chronostratigraphic data after Bergström et al. (2009), Budil et al. (2011), Fatka et al. (2013) and Kraft et al. (2015).

de Moncorvo area, V. cf. iberica (Hammann, 1976) occurs in the lower part of the Chăo do Amieiral Formation, of middle Berounian (global late Sandbian/early Katian) age (see Sá et al. 2005 for further information on the lithostratigraphy and palaeontology of the unit, and Pereira et al. 2015a for detailed stratigraphy of the locality and its trilobite assemblage). The base of this unit is marked by an oolitic ironstone bed (the Chôsavelha Bed), which correlates with the previously mentioned Zdice-Nučice Ironstone 'Horizon' of the Czech Republic. In the Buçaco region, $V$. cf. iberica occurs in oolitic ironstones of the Favaçal Bed at the base of the Louredo Formation. This bed correlates with the Chôsavelha Bed. Specimens of $V$. iberica from this region came from the overlying Porto de Santa Anna Formation, the base of which is also marked by an ironstone bed of late Berounian age, this species being the most common trilobite in it. In the Mação region, V. iberica occurs in the Cabeço do Peão Formation (see Young 1988 for lithostratigraphy, and Pereira et al. 2015b for information on the locality), which correlates with the Chão do Amieiral and Louredo formations.

Spain. - Spanish specimens of Vysocania came from two regions: the Fombuena locality in the province of Zaragoza, in the northeastern part of the country (locality 6, Fig. 1A); and the Almadén locality, in the Province of Ciudad Real in the south-central part of the country. The Fom- buena specimens of Vysocania sp. came from the Huerva Member in the middle part of the Fombuena Formation (see Zamora et al. 2014 for information on local lithostratigraphy and the locality). This formation correlates with the middle Berounian units of Portugal. In the Ciudad Real region, Vysocania iberica occurs in the upper Berounian (ca. global lower Katian, Ka2) 'upper coquinoid' beds (type-horizon of this species) of the Bancos Mixtos Formation (see Hammann 1976 for fossil localities).

Morocco. - The specimens of Octillaenus marocanus sp. nov. originate from Jbel Bou Ingarf (Fig. 1C), located between Zagora and Alnif, in the Drâa-Tafilalet region of southeastern Morocco. The type material was collected from about $40 \mathrm{~m}$ below the so-called 'Ouzregui Bed' (= Dreyfussina struvei bed of previous authors), in the uppermost part of the Upper Ktaoua Formation (Fig. 2), upper Kralodvorian (global upper Katian, Ka4). For further information on the stratigraphy and locality see Loi et al. (2010).

\section{Systematic palaeontology}

Repository acronyms are as follows: CMP - Miguel Pires collection and CMG - Marques Guedes collection, Departamento de Geologia from the Faculdade de Ciências da 
Universidade de Lisboa (Lisbon, Portugal); MG - Museu Geológico de Lisboa (Lisbon, Portugal); MGUTAD - Museu de Geologia Fernando Real from the Universidade de Trás-os-Montes (Vila Real, Portugal); MGM - Museo Geominero of the Instituto Geológico y Minero de España (Madrid, Spain); MPZ - Museo de Ciencias Naturales de la Universidad de Zaragoza (Zaragoza, Spain); NHM - Natural History Museum (London, England); SMF - Senckenberg Museum (Frankfurt, Germany); NMP - Národní muzeum (Prague, Czech Republic); CGS - Česká geologická služba (Prague, Czech Republic) and MBHR - Muzeum Dr. Bohuslava Horáka v Rokycanech (Rokycany, Czech Republic).

Order Corynexochida Kobayashi, 1935

Suborder Illaenina Jaanusson, 1959

Family Illaenidae Hawle \& Corda, 1847

\section{Genus Vysocania Vaněk \& Vokáč, 1997}

Type species. - Zbirovia vaneki Šnajdr, 1958, Bohdalec Formation, upper Berounian (ca. global Ka2 stage slice, lower Katian; after Fatka et al. 2013 and Gutiérrez-Marco et al. 2017), Czech Republic.

Diagnosis. - Cranidium semi-circular in outline, very convex (sag. and tr.), weakly overhanging anterior margin; corset-shaped glabella (45-50\% cranidial width posteriorly); axial furrows about one-third of the cranidial length; palpebral lobes of small to moderate size, located about their own length from posterior margin of cranidium; librigena subtrapezoidal, longer (exsag.) than wide (tr.), usually with pointed genal angle; thorax of nine segments, with narrow axis (approx. $40 \%$ of thoracic width anteriorly); rostral plate subtrapezoidal, with a length/width ratio about $28 \%$, oblique and straight connective sutures (diverging forwards at about $70^{\circ}$ to sagittal line) and a transverse depression posteromedially; hypostome width across anterior wings about $160 \%$ of sagittal length, lateral and posterior borders narrow and subparabolic in outline (medial part of posterior margin transverse), without shoulders, anterior lobe of the middle body strongly convex (tr. and sag.), occupying about $70 \%$ of the hypostomal length, posterior lobe slightly inflated, no maculae; pygidium subpentagonal to subelliptical in outline, length/width ratio from $55 \%$ to $70 \%$; axis narrow ( $25 \%$ of pygidial width anteriorly), defined mainly by deflection of anterior margin; pygidial doublure with a medial forwardly directed deflection, about $35-50 \%$ of pygidial length.

Other species. - Vysocania iberica (Hammann, 1976), upper part of the Bancos Mixtos Formation, upper Berounian (ca. Ka2, lower Katian), Corral de Calatrava and Almadén areas, Spain; also known in the Queixopęrra Member,
Cabeço do Peão Formation, middle Berounian ( $c a$. upper Sandbian to lower Katian), Mação and in the lower half part of the Porto de Santa Ana Formation, upper Berounian (ca. Ka2, lower Katian), Buçaco, Portugal; V. moraveci sp. nov., Libeň Formation (also Letná Formation), lower Berounian (ca. Sandbian), Czech Republic; V. panderi (Barrande, 1852), Zahořany Formation (also Vinice Formation), middle Berounian (upper Sandbian to lower Katian), Czech Republic.

Other references to Vysocania. - In Ibero-Armorica (Portugal, Spain and France), the records of Vysocania were previously reported as Dysplanus (Zetillaenus) or Zetillaenus. Although several authors reported the presence of $V y$ socania specimens in the Spanish middle Berounian, they have never been the subject of a systematic study: Kolb (1978, pl. 1, figs 11, 12) identified and figured Dysplanus (Zetillaenus)? sp. from the Piedra del Tormo and Huerva members of the Fombuena Formation from the Zaragoza region; Hammann et al. (1982) identified Dysplanus (Z.) cf. ibericus in the 'Cuarcitas de Colmenarejos' Formation from the Sierra del Tremedal region; Rábano (1984) mentioned the presence of $D$. (Z.) ibericus in the Collado de la Plata area, from a lateral equivalent of the Fombuena Formation; and Portero García et al. (1988) identified Dysplanus (Zetillaenus) sp. in the basal ironstone of the middle Berounian 'Pizarras Cantera' Formation from the Ciudad Real region. The material from the Huerva Member of the Fombuena Formation was revised for this work and assigned to Vysocania sp. Also, the identifications of Dysplanus (Zetillaenus) sp. in the upper Berounian to Kralodvorian Rosan Formation, from the Finistère region, France (Babin \& Darboux 1982, p. 7), and Stenopareia sp. in the Lower Ktaoua Formation of Morocco (Álvaro et al. 2007, p. 32), probably correspond to Vysocania. Concerning the identifications of specimens from the Upper Ordovician Monte Orri Formation of Sardinia (Zetillaenus cf. ibericus; Hammann \& Leone 1997, pl. 15, figs 1, 2, 5) and the SartBernard Formation of Belgium (Stenopareia aff. panderi; Owens \& Servais 2007, fig. 6e), it is not possible to confirm the generic assignments due to the rare occurrence, flattening and fragmentary preservation of the specimens coming from both of those units.

Remarks. - Confusion regarding the generic affinities of certain species here assigned to Vysocania dates back to the proposal of Stenopareia by Holm (1886) as a subgenus of Illaenus to encompass several species from the Ordovician of the Baltic region and the United Kingdom, as well as 'Illaenus' panderi from Bohemia. Jaanusson (1954) retained 'I.' panderi in Stenopareia, as did Šnajdr (1957) who also included the Czech species 'Illaenus' oblitus Barrande, 1872 while highlighting differences between 'I.' panderi and Baltic Stenopareia species in the glabellar 
muscle scars, rostral plate and hypostome. Most later authors (e.g. Shaw 2000, Bruthansová 2003) accepted the assignment of 'I.' panderi to Stenopareia, but Vaněk \& Valíček (2001) assigned 'I.' panderi with question to Vysocania, which Bruthansová (2003) subsequently regarded as a junior synonym of Stenopareia. However, several dorsal and ventral morphological characters separate Stenopareia from Vysocania. Stenopareia has a relatively larger (tr.) glabella, usually defined by straighter dorsal furrows. In the librigenae, the genal angles are broadly rounded (in $V y$ socania they typically bear a short genal spine or show a pointed outline, except in $V$. panderi which has a slightly rounded genal angle). The glabellar musculature in Stenopareia (see Owen \& Bruton 1980, pl. 3, fig. 10 and Bruton \& Owen 1988, fig. 9n-p) is composed of four pairs of branched irregular scars, which decrease in size anteriorly (in Vysocania they are subcircular, according to Šnajdr 1957, text-fig. 3). The thorax of Stenopareia has a wider axis, corresponding to almost $50 \%$ of the anterior thoracic width, gently tapering posteriorly to $80 \%$ of its anterior width (the axis of Vysocania represents only $35 \%$ of the thoracic width anteriorly and is approximately $60 \%$ as wide posteriorly as anteriorly). The pygidial axis of Stenopareia is also wider, about $40 \%$ of the maximum pygidial width anteriorly (in Vysocania this ratio equals $25 \%$ ). Therefore, the axial lobe of the entire exoskeleton of Stenopareia is wider (tr.) than in Vysocania.

The ventral morphology also shows noteworthy differences between representatives of both genera. Stenopareia displays a rostral plate with less oblique connective sutures (diverging $50^{\circ}$ to sagittal line, compared to $70^{\circ}$ in Vysocania; compare Fig. 7H herein and Owen \& Bruton 1980, pl. 4, figs 4, 13). The posterior medial depression of Vysocania (Figs 4C, 7H-I) is absent in Stenopareia, in which the rostral plate has a dorsally and forwardly deflected subtriangular flange (Owen \& Bruton 1980, pl. 4, fig. 9). The hypostome of Stenopareia has a different outline (compare Figs 7J, 8A and Owen \& Bruton 1980, pl. 4, fig. 11), being subquadrangular, with rounded posterolateral corners (the Vysocania hypostome is roughly parabolic in outline, with the posterior margin transverse medially); the lateral border furrow is broad, the middle furrow is situated towards the back of the middle body, and the maculae are prominent (in Vysocania the middle furrow is oblique and located far forward, and there are no maculae.

Another important factor contributing to misunderstanding of the affinities of species belonging to Vysocania relates to Zetillaenus Šnajdr, 1957 (Fig. 11F-M), the type species of which is 'Illaenus' wahlenbergianus Barrande, 1852 from the Králův Dvůr Formation of the Prague Basin. In erecting 'I.' wahlenbergianus, Barrande (1852, p. 683) contrasted the presence of a genal spine in this species with what he described as the rounded genal angle of 'I.' panderi. Consequently, the presence of a genal spine in Vysocania iberica may have played a role in relating that species to Zetillaenus (e.g. Thadeu 1947, p. 222; Hammann 1976, 1992; Young 1985; Romăo et al. 1995; Hammann \& Leone 1997). Although sharing similar general morphology, Vysocania and Zetillaenus clearly differ in a series of dorsal and ventral features. In Zetillaenus (Fig. 11F, K) the cephalon and pygidium are parabolic in outline (semicircular in Vysocania); and the longitudinal cranidial profile describes an arc of circle (the anterior cranidial region is more strongly convex in Vysocania). Concerning ventral features, Zetillaenus has a longer (sag.) rostral plate (Fig. 11G, I), the hypostome has distinct shoulders (Fig. 11H), (shoulders absent in Vysocania; Figs 7J, 8A); and the pygidial doublure is shorter (sag.; compare Fig. 8K and Fig. 11K).

Occurrence. - Upper Ordovician (Sandbian to lower Katian, Ka2; regional lower Berounian to upper Berounian stage) of Czech Republic, Portugal, Spain and possibly France.

\section{Vysocania vaneki (Šnajdr, 1958)}

Figure 3

1958 Zbirovia vaneki sp. nov.; Šnajdr, pp. 207-211, text-figs. 1, 2; pl. 1, figs 1-9; pl. 2, figs 10-20.

1966 Stenopareia vaneki. - Havlíček \& Vaněk, p. 58, pl. 12, fig. 10.

1992 Ulugtella vaneki. - Hammann, p. 76.

1997 Vysocania vaneki. - Vaněk \& Vokáč, p. 28, pl. 2, figs 12-21.

2001 Vysocania vaneki. - Vaněk \& Valíček, p. 33.

partim 2003 Stenopareia panderi. - Bruthansová, pp. 178-181.

2003 Stenopareia vaneki. - Bruthansová, pp. 180, 181, figs $12 \mathrm{f}-\mathrm{i}$.

Holotype. - Internal mould of a pygidium (NMP L17619, figured by Šnajdr 1958, pl. 2, fig. 16 and Bruthansová 2003, fig. 12i).

Type horizon and locality. - Bohdalec Formation, upper Berounian ( ca. Ka2, lower Katian), Hloubětín, Czech Republic.

Material. - Two enrolled specimens (CGS JV2294, JV2295-3); one cephalon (CGS JV2295-1); three cranidia (CGS JV10392, JV2295-3, MS3); one rostral plate (CGS Mu7); one thoracopygon (CGS JV2295-4); seven pygidia (CGS JV46, JV 1373, JV1431, JV2295-2, JV 10392, JV10403, JV 10421); three meraspides (cranidium, NMP L33192; pygidia, degree 4, NMP VH5176-1; degree 6, NMP A3). 
Diagnosis. - Cranidium subrectangular; glabella narrow (width at lunette about $30 \%$ of maximum cranidial width); axial furrows strongly bent at lunette; anterior section of facial suture straight; librigena with short genal spine; pygidium subpentagonal, length/width ratio about $65 \%$; maximum pygidial width level with posterior end of axis; axis parabolic, anteriorly about $28-30 \%$ of maximum pygidial width, flat, axial furrows indistinct; doublure corresponding to $35 \%$ of sagittal pygidial length.

Remarks. - For detailed description see Šnajdr (1958, pp. 208-210) and Vaněk \& Vokáč (1997, p. 28). The species $V$. vaneki, originally described as lacking eyes, was firstly established as a member of Zbirovia (Šnajdr 1958) and later tentatively re-assigned by Hammann (1992) to Ulugtella Petrunina in Repina et al. (1975). The revision of Vaněk \& Vokáč (1997) showed the presence of palpebral lobes and a small genal spine in $V$. vaneki and these authors considered that all the Vysocania material from the upper Berounian Bohdalec Formation belongs to V. vaneki. However, Bruthansová (2003) considered both Vysocania panderi and $V$. vaneki to be represented in the Bohdalec Formation. Herein we follow the opinion of Vaněk \& Vokáč (1997) that specimens from the Bohdalec Formation previously identified as $V$. panderi belong to $V$. vaneki. The latter species is differentiated from $V$. panderi by a narrower (tr.) glabella, a librigena with short genal spine, a shorter (sag.) pygidium with more subpentagonal outline, a shorter (sag.) pygidial doublure and the generally smaller size of the specimens.

\section{Vysocania iberica (Hammann, 1976)}

Figures 4, 5A-J

1908 Illaenus cf. panderi Barr. - Delgado, pp. 31, 57.

1947 Illaenus wahlenbergianus Barrande. - Thadeu, p. 222, pl. 2, fig. 4 .

partim 1976 Dysplanus (Zetillaenus) ibericus n. sp.; Hammann, pp. 51-53; text-fig. 5; pl. 2, figs 23-25; pl. 3, figs 26, 27-33, 35-37; non pl. 3, figs 28, 34, $?=$ Cekovia loredensis (Thadeu, 1947).

1985 Dysplanus (Zetillaenus) sp. A. - Young, pp. 399, 400, pl. 48, fig. 15 .
1985 Dysplanus (Zetillaenus) ibericus Hammann, 1976. - Young, p. 401; pl. 48, fig. 13.

1987 Dysplanus (Z.) ibericus. - Gutiérrez-Marco \& Rábano, p. 651.

1995 Zetillaenus sp. - Romão et al., p. 124.

2000 Zetillaenus sp. - Romão, tab. 2.4.

2011 Zetillaenus wahlengergianus? - Sá et al., p. 31.

Holotype. - Internal mould of a cranidium (SMF 24860, figured by Hammann 1976, pl. 3, fig. 26).

Type horizon and locality. - Upper part ('upper coquinoid' beds) of the Bancos Mixtos Formation; locality Al I (in Hammann 1976, p. 37), north of Almáden, Spain.

Material. - Bancos Mixtos Formation (Spain): the type-material listed by Hammann (1976, p. 51).

Queixopęrra Member, Cabeço do Peão Formation (Portugal): thirteen exoskeletons (MG 91-2/100; CMG 0009, 0012a with counterpart 0012b, 0036, 0073; CMP 0095, 0142, 0200, 0295, 0297-1a with counterpart 0297-1b, 0297-2a with counterpart 0297-2b, 0300-1, 0300-2); nine cranidia (MGUTAD 15544, 15540, 15152, 15046, 15048, 15043, 15403; CMP0068, 0300-3); one pygidium (MGUTAD 15393); one meraspid pygidium (degree 7: CMP 0298).

Porto de Santa Anna Formation (Portugal): five exoskeletons (MG 2815-1, 214-a with counterpart 214-b, 214-2, 216, 216-2); four cranidia (MG 2813-8, 2813-11, 2813-12, 2805-2); one thoracopygon ( $\mathrm{MG} 2815-2)$; four pygidia (MG2815-2, 2818-1, 2820-2, 2820-4); one meraspid exoskeleton (degree 8: MG 2805).

Diagnosis. - Cephalic axial furrows gently curved; palpebral lobes corresponding to $18-19 \%$ of cranidial length; librigena bearing a short genal spine; pygidial length/width ratio from $58 \%$ to $65 \%$; maximum pygidial width across posterior limit of axis; axial furrows indistinct; axis about $40 \%$ of pygidial length.

Description. - Cephalon semicircular, with maximum width (at posterior margin) of $160 \%$ of sagittal length. Cranidium strongly vaulted (sag. and tr.). Glabella corsetshaped, slightly exceeding height of fixigena in lateral

Figure 3. Vysocania vaneki (Šnajdr, 1958) from Bohdalec Formation, upper Berounian (ca. lower Katian, Ka2), Czech Republic; A - CGS MS3, oblique view (internal mould of a cranidium); B, C - NMP L33192, dorsal (B) and lateral (C) views (internal mould of a meraspid cranidium); D - CGS JV10392, dorsal view (internal mould of a cranidium); E - CGS JV2295e, dorsal view (internal mould of an enrolled exoskeleton); F - CGS JV2294a, oblique view (external mould of an enrolled specimen); G - CGS JV2295c (lateral view of a cephalon); H - CGS JV46, dorsal view (internal mould of a pygidium); I - CGS Mu7, ventral view (composite mould of cephalic doublure); J - CGS JV1431, dorsal view (internal mould of a pygidium); K - CGS JV10373b, dorsal view (internal mould of a pygidium and external mould of a cranidial fragment); L - CGS Mu2, dorsal view (internal mould of a thoracopygon); M - CGS JV10421, dorsal view (internal mould of a pygidium); N - NMP VH5176-1, dorsal view (internal mould of a meraspid pygidium, degree 4); O - NMP A3, dorsal view (internal mould of a meraspid pygidium, degree 6). Scale bars: A, D-M = $5 \mathrm{~mm} ; \mathrm{B}, \mathrm{C}, \mathrm{N}, \mathrm{O}=2 \mathrm{~mm}$. 
Sofia Pereira et al. - The illaenid trilobites Vysocania and Octillaenus from the Upper Ordovician
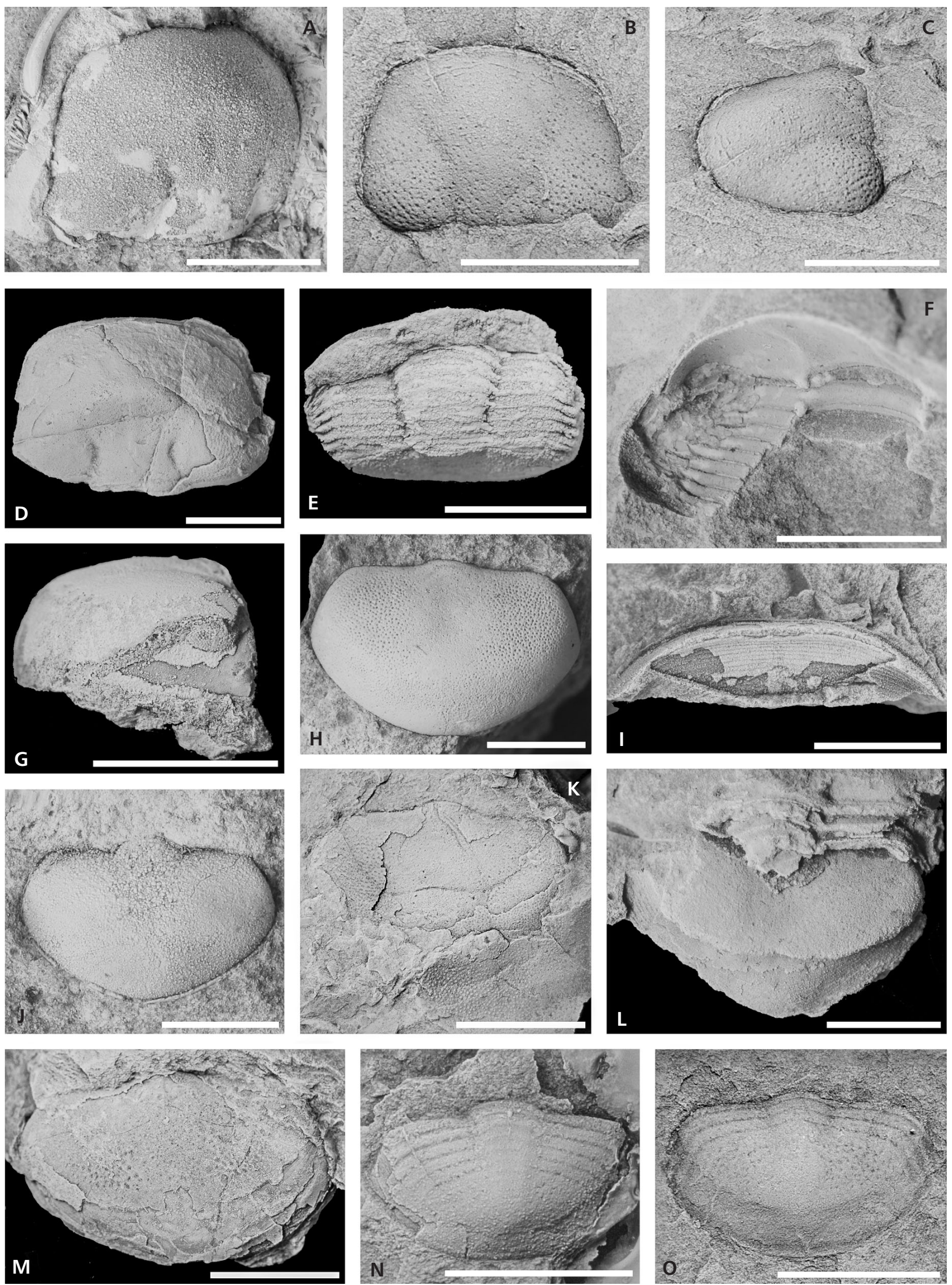
view, merging with fixigenae anteriorly; maximum glabellar elevation at posterior quarter of glabellar length, sloping downwards anteriorly with strongly rounded profile; posterior glabellar width corresponding to $40-45 \%$ of maximum cranidial width. Axial furrows moderately deep, broad (tr.), reaching from $35 \%$ to $40 \%$ of sagittal cranidial length, converging gently forwards as far as lunette (opposite palpebral lobe), thereafter diverging, considerably shorter in front of lunette than behind, dying out abruptly. A broad (sag.) furrow (most distinct on internal moulds) close to the posterior edge of the glabella and parallel with it is interpreted as the occipital furrow. A median glabellar tubercle, only observed on the internal moulds, is present in front of the occipital furrow (Fig. 4A). Fixigenae subrectangular, width at palpebral lobes of $20 \%$ of maximum cephalic width; posterior border furrow on fixigena anteriorly arched, in transversal line with the occipital furrow. Posterior branch of facial suture short (exsag.), converging posteriorly; anterior branch of the facial suture divergent, initially straight in front of palpebral lobe, curving inwards anterior to $60 \%$ of cranidial length. Palpebral lobe situated about its own length from posterior edge of cephalon. Librigenae subtriangular to subtrapezoidal, small, with a narrow and short (about $50 \%$ of length of eye) genal spine directed posterolaterally, its outer margin almost continuous in outline with the librigenal lateral margin; maximum librigenal width across posterior border. Doublure extending to the librigenal adaxial margin, bearing at least 15 equally spaced terrace ridges subparallel to the librigenal margin. Cranidial sculpture of uniformly sized pits, anteriorly interspersed with slightly sinuous but rarely preserved terrace ridges. Rostral plate lenticular in outline, about $28 \%$ as wide at posterior end of connective suture as at anterior end, crossed posteromedially by shallow depression; connective suture converging backwards at $70^{\circ}$ to sagittal line.

Thorax composed of nine segments, first three longer (sag., exsag.) than remainder, all of uniform width (tr.). Axis moderately arched (tr.), narrowing backwards, more strongly in last five segments, approximately $60 \%$ as wide posteriorly as anteriorly. Axial furrow deeper than on cephalon; subcircular axial processes visible on internal moulds. Pleurae successively increasing in width (tr.) posteriorly and fulcrum located successively farther from axial furrow, at 30\% of pleural width on first segment and 50\% on last segment. Inner portion of pleura flat and smooth; outer portion deflected backwards and strongly downwards, bearing a broad (exsag., tr.) and smooth facet. Sculpture of indistinct pits on thoracic axis and inner part of pleurae, weaker than on cephalon and visible only on external surface; outer part of pleurae with subtransverse terrace ridges, about 20 on articulating facets.

Pygidial axis subtriangular to subparabolic, weakly convex, flat or even concave in transverse profile, anterior width about $25 \%$ of maximum pygidial width (level with posterior end of axis). Axial furrow not defined. Pleural areas smooth; pleural facet wide, about 50\% of anterior pleural width, oriented at about $110^{\circ}$ to sagittal line, with terrace ridges with similar configuration as on thoracic pleural facets. Dorsal surface of pygidium, excluding pleural facets, with similar pitted sculpture as cranidium, less dense in axial than pleural region. Doublure corresponding to $50 \%$ of pygidial length medially, decreasing to $40 \%$ laterally; inner margin with forward deflection medially; sculpture of about 15 similarly spaced (about $0.25 \mathrm{~mm}$ ) terrace ridges running subparallel to pygidial margin, becoming more sinuous medially.

Remarks. - The type-material of Vysocania iberica, deposited in the Senckenberg Museum (Frankfurt, Germany), comprising deformed and fragmentary specimens, was revised for this work. We consider that among this type-material at least two different illaenids are represented: V. iberica and Cekovia $\mathrm{cf}$. loredensis (see synonymy of Vysocania iberica herein).

\section{Vysocania cf. iberica (Hammann, 1976)}

\section{Figure $5 \mathrm{~K}-\mathrm{M}$}

2015a Stenopareia (Vysocania) sp. - Pereira et al., p. 62, figs $1 \mathrm{c}, \mathrm{d}$.

Material. - Chão do Amieiral Formation (Torre de Moncorvo, Portugal): one cranidium (MGUTAD 15703); one pygidium (MGUTAD 15704).

Louredo Formation (Buçaco, Portugal): one pygidium as counterpart moulds (MGUTAD 15705a, 15705b).

Figure 4. A-G - Vysocania iberica (Hammann, 1976) from Bancos Mixtos Formation, upper Berounian (ca. lower Katian, Ka2), Almáden, Spain; A, B - SMF 24873 (paratype), dorsal (A) and lateral (B) views (internal mould of a cranidium); C - SMF 24872 (paratype), ventral view (internal mould of a rostral plate); D - SMF 24873-2 (paratype), dorsal view (internal mould of a cranidium); E - SMF 24874 (paratype), dorsal view (internal mould of a pygidium); F - SMF 24871 (paratype), dorsal view (composite mould of a pygidium); G - SMF 24861 (paratype), dorsal view (internal mould of a meraspid pygidium, degree 7). • H-L - Vysocania iberica (Hammann, 1976) from Cabeço do Peăo Formation, middle Berounian (upper Sandbian/lower Katian), Maçăo, Portugal. • H - CMP 0300, dorsal view (internal moulds of two exoskeletons and one cephalon); I - CMP 0142, dorsal view (internal mould of an exoskeleton); J - CMP 0200, lateral view (internal mould of an exoskeleton); $\bullet \mathrm{K}$, L - CMG 0012, dorsal views. Detail of the librigena of the internal mould of an exoskeleton $(\mathrm{K})$, and latex cast of the external mould of the exoskeleton $(\mathrm{L})$. Scale bars $=5 \mathrm{~mm}$; except in $\mathrm{G}$, $\mathrm{K}$ $(=2 \mathrm{~mm})$. 
Sofia Pereira et al. - The illaenid trilobites Vysocania and Octillaenus from the Upper Ordovician
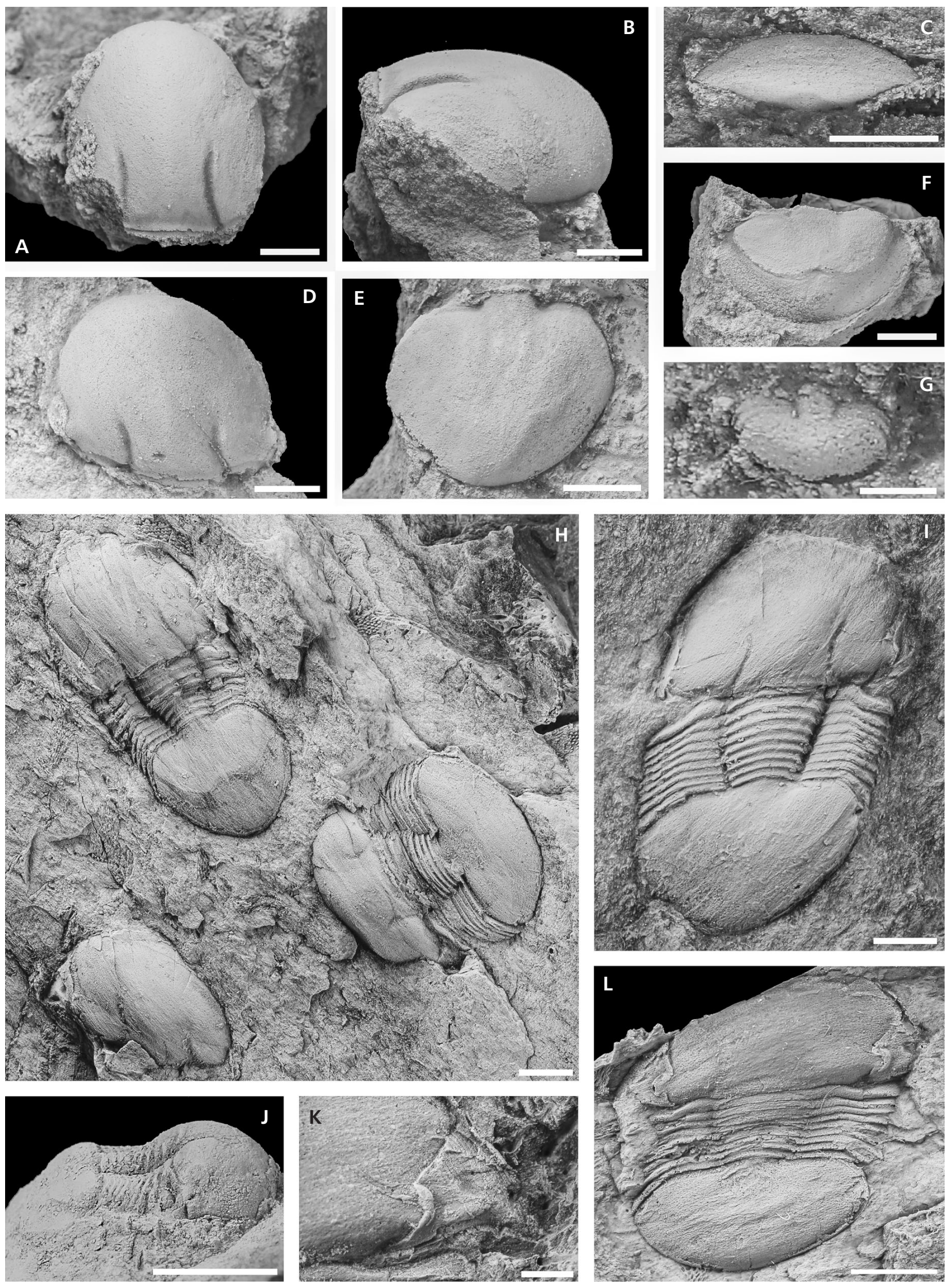
Remarks. - The specimens are too poorly preserved for specific identification. However, the presence of the main diagnostic characters of Vysocania supports the generic assignment. One cranidium (Fig. 5K) preserves a gently curved axial furrow typical of $V$. iberica. Based on this feature, and considering the geographical and chronostratigraphic context, this material is tentatively assigned to the only known Iberian species of Vysocania.

Occurrence. - Chão do Amieiral Formation, Torre de Moncorvo (Mós), and Louredo Formation, Buçaco (Louredo), from the middle Berounian ( $c a$. upper Sandbian to lower Katian) of Portugal.

\section{Vysocania moraveci sp. nov.}

Figure 6

partim 1957 Stenopareia panderi. - Šnajdr, pp. 160-166, pl. 7, fig. 3 [non pl. 7, figs 4-7 = Vysocania panderi].

2001 Harrisia rumpalensis Moravec (MS). - Vaněk \& Valíček, p. 33 [nomem nudum].

2001 Harrisia omega Moravec (MS). - Vaněk \& Valíček, p. 33 [nomem nudum].

2002 Harrisia rumpalensis. - Moravec, p. 56 [nomen nudum].

partim 2003 Stenopareia panderi. - Bruthansová, pp. 178-180.

2006 Harrisia rumpalensis Moravec (MS). - Vaněk \& Valíček, p. 28 [nomen nudum].

2006 Harrisia omega Moravec (MS). - Vaněk \& Valíček, p. 28 [nomen nudum].

2011 Stenopareia panderi. - Mergl \& Budil, p. 111, fig. $1 \mathrm{i}, \mathrm{j}$.

Holotype. - Internal mould of a pygidium (CGS JV10511; Fig. 6A, B).

Paratypes. - Two incomplete exoskeletons (CGS JV10497, JV10505); seven cranidia (CGS JV10397-2, JV10400-2, JV10507, JV10510-JV10512, JV10513-1); fourteen pygidia (CGS JV10395, JV10397-1, JV10400-1, JV10504, JV10506, JV10507, JV10509, JV10513-2, JV10514-JV10519).

Type horizon and locality. - ̌̌ Revnice Quartzite of the Libeň Formation (lower Berounian, ca. Sandbian), Zbiroh (49 49 $\left.55^{\prime \prime} \mathrm{N} ; 13^{\circ} 47^{\prime} 12^{\prime \prime} \mathrm{E}\right)$, Plzeň region, Rokycany district, Czech Republic.

Other material. - Libeň Formation: one cranidium (CGS MS1746); four pygidia (CGS MS1750, MS1751, MS10658; MBHR 6166).

Letná Formation: one incomplete exoskeleton (NMP 23937-3); one cephalon (CGS JV 1502); two cranidia (NMP 23937-1, 23937-2).
Etymology. - After Josef Moravec (Nepomuk, Czech Republic), a private investigator in palaeontology. He was a pioneer in recognizing the different identity of Vysocania specimens from the Libeň Formation.

Diagnosis. - Exoskeleton small (10-15 mm of sagittal length), with moderately curved cephalic axial furrows extending almost $50 \%$ of cranidial length; librigena with pointed genal angle; pygidium with posterior margin slightly ogival, length/width ratio low (from 55\% to 65\%); maximum pygidial width across posterior limit of axis; axis about $40 \%$ of pygidial length and $27 \%$ of maximum pygidial width, parabolic, weakly convex, defined by faint axial furrows.

Description. - Cephalon semicircular, with maximum width at posterior margin. Cranidium strongly vaulted (sag. and tr.). Glabella corset-shaped, slightly exceeding height of fixigena in lateral view, merging with fixigenae anteriorly; maximum glabellar elevation at posterior quarter of glabellar length, sloping downwards anteriorly with strongly rounded profile; posterior glabellar width corresponding to $45-50 \%$ of maximum cranidial width. Axial furrows moderately deep, broad (tr.), converging gently forwards as far as lunette (opposite palpebral lobe), thereafter diverging. A broad (sag.) furrow (most distinct on internal moulds) close to the posterior edge of the glabella and parallel with it is interpreted as the occipital furrow. Fixigenae subrectangular; posterior border furrow on fixigena anteriorly arched, in transversal line with the occipital furrow. Posterior branch of facial suture short (exsag.), converging posteriorly; anterior branch of the facial suture divergent, initially straight in front of palpebral lobe, curving inwards at the anterior cephalic margin. Palpebral lobe situated about half of its own length from posterior edge of cephalon. Librigenae subtriangular to subtrapezoidal; maximum librigenal width across posterior border. Thorax composed of nine segments, all of uniform width (tr.). Axis moderately arched (tr.), narrowing backwards, more strongly in last five segments, approximately $55 \%$ as wide posteriorly as anteriorly. Axial furrow moderately deep; subcircular axial processes visible on internal moulds. Inner portion of pleura flat and smooth; outer portion deflected backwards and strongly downwards, bearing a broad (exsag., tr.) facet.

Pygidial axis subparabolic, weakly convex to flat in transverse profile. Pleural areas smooth; pleural facet wide, about $50 \%$ of anterior pleural width. Dorsal surface of pygidium with pitted sculpture as cranidium. Doublure corresponding to $50 \%$ of pygidial length medially, slightly decreasing laterally; inner margin with forward deflection medially.

Remarks. - In general morphology, V. moraveci is similar 

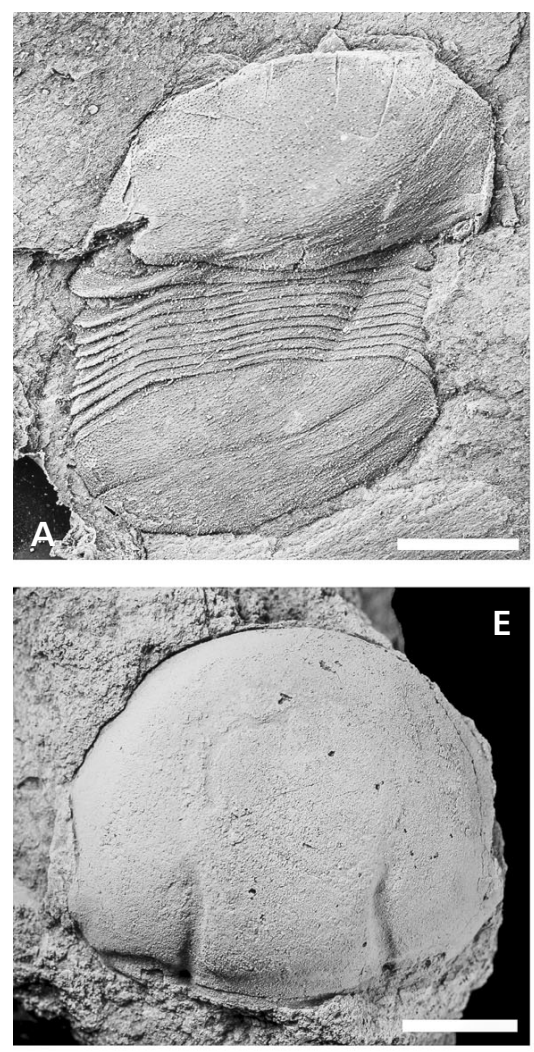

E
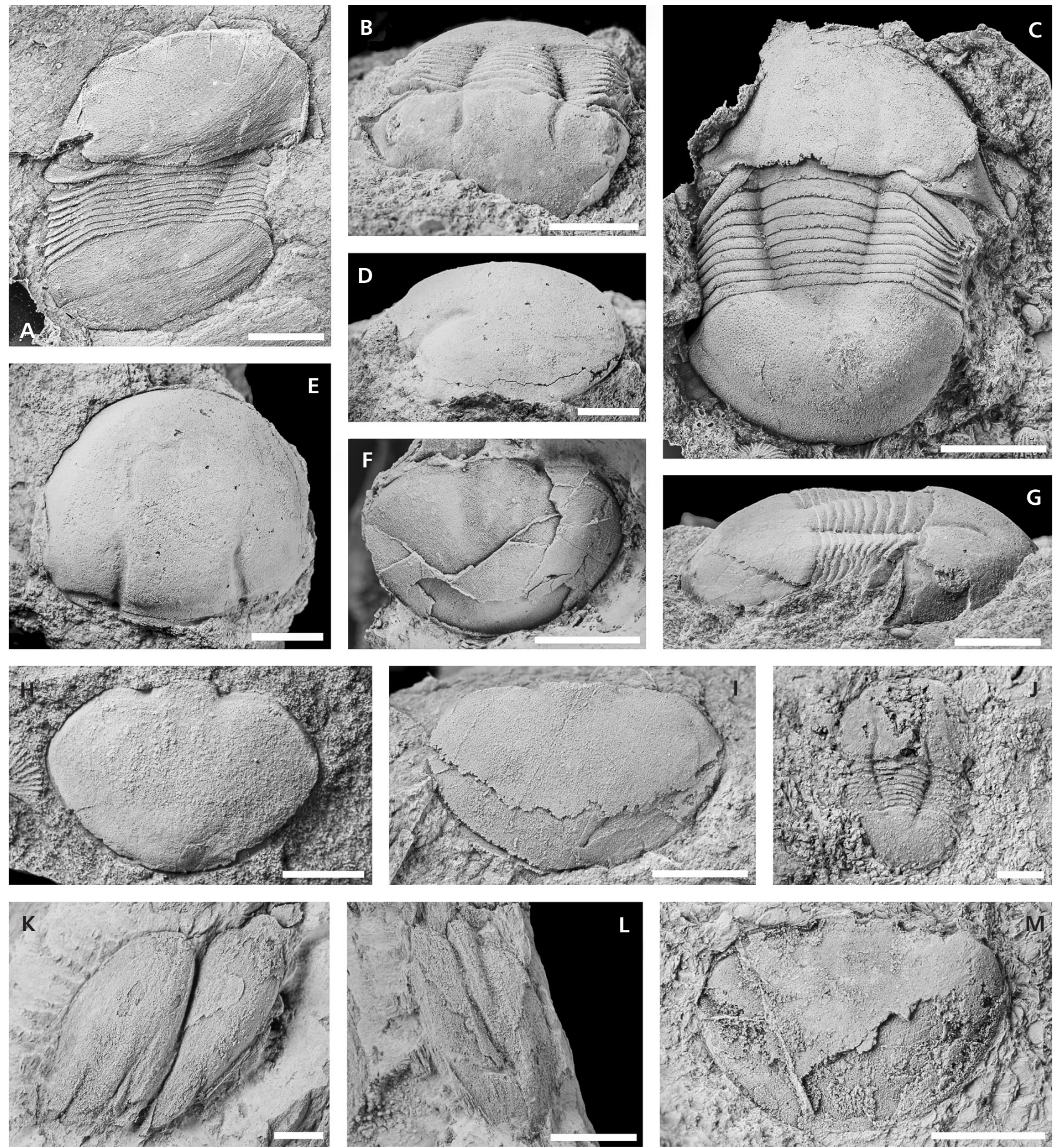

Figure 5. A-J - Vysocania iberica (Hammann, 1976) from Porto de Santa Anna Formation, upper Berounian (ca. lower Katian, Ka2), Buçaco, Portugal; A - CMP 0295, dorsal view (latex cast of the external mould of an exoskeleton); B, C, G - MG 214, anterior (B), dorsal (C) and lateral (G) views (internal moulds, B, G, and latex cast of the external mould, C, of an exoskeleton); D, E- MG 2813-11, lateral (D) and dorsal (E) views (internal mould of a cranidium); F-MG 2533, dorsal view (internal mould of a pygidium); H - MG 2818-1, dorsal view (internal mould of a pygidium); I - MG 2820-4, dorsal view (composite mould of a pygidium); J-MG 2805, dorsal view (internal mould of a meraspid exoskeleton, degree 8 ). $\bullet \mathrm{K}-\mathrm{M}-$ Vysocania cf. iberica (Hammann, 1976); K-L - from the Chăo do Amieiral Formation, middle Berounian (upper Sandbian/lower Katian), Moncorvo, Portugal; M - from the Louredo Formation, middle Berounian (upper Sandbian/lower Katian), Buçaco, Portugal; K - MGUTAD 15703, dorsal view (internal mould of a cranidium); L-MGUTAD 15704, dorsal view (composite mould of a pygidium); M-MGUTAD 15705, dorsal view (composite mould of a pygidium). Scale bars $=5 \mathrm{~mm}$ except in $\mathrm{J}(=2 \mathrm{~mm})$. 

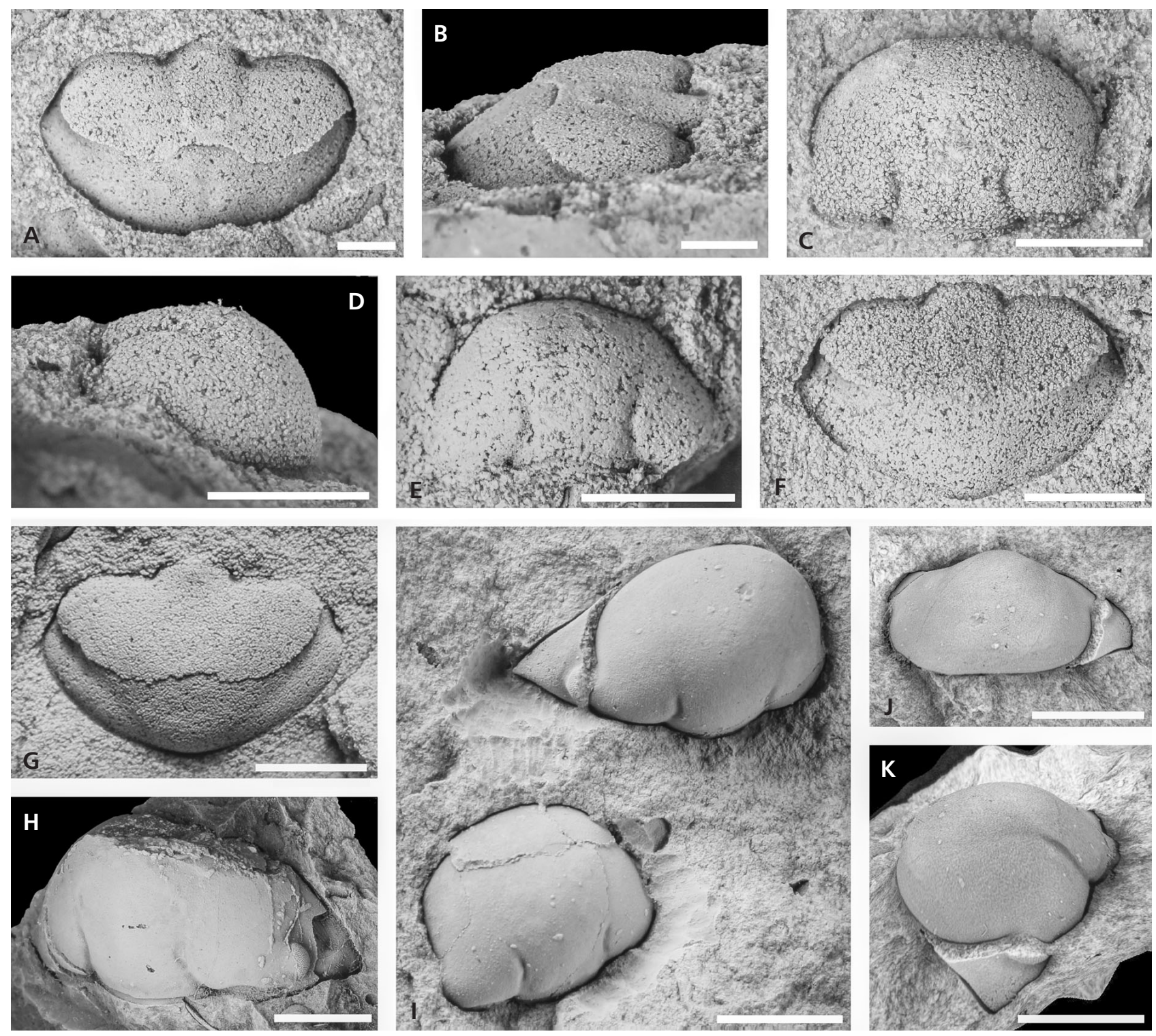

Figure 6. A-G-Vysocania moraveci sp. nov. from Libeň Formation, lower Berounian (ca. Sandbian), Zbiroh (A-F) and Rumpál (G), Czech Republic; A, B - CGS JV10511 (holotype), dorsal (A) and lateral (B) views (composite mould of a pygidium); C, D - CGS MS1746, dorsal (C) and lateral (D) views (internal mould of a cranidium); E - JV 10512a, dorsal view (internal mould of a cranidium); F - CGS MS10658, dorsal view (composite mould of a pygidium); G - MBHR 6166, dorsal view (composite mould of a pygidium). $\bullet \mathrm{H}-\mathrm{K}-$ Vysocania moraveci sp. nov. from Letná Formation, lower Berounian ( $c a$. Sandbian), Chrustenice, Czech Republic; H - CGS JV1502, oblique view (internal mould of a cephalon); I, J, K - NMP 23937, dorsal (I), anterior (J) and lateral (K) views (internal moulds of one cephalon and one cranidium). Scale bars $=5 \mathrm{~mm}$ except in $\mathrm{A}, \mathrm{B}(=2 \mathrm{~mm})$.

Figure 7. A - Vysocania panderi (Barrande, 1852) from Vinice Formation, middle Berounian (upper Sandbian/lower Katian), Trubín, Czech Republic. NMP 35050, dorsal view (internal mould of an exoskeleton). B-J - Vysocania panderi (Barrande, 1852) from Zahořany Formation, middle Berounian (upper Sandbian/lower Katian), Czech Republic; B - CD 1112, dorsal view (internal mould of an exoskeleton); C - NMP L46553, dorsal view (internal mould of an exoskeleton); D - NMP L15610, dorsal view (internal mould of an exoskeleton); E - NHM42609-1, dorsal view (internal moulds of two exoskeletons); F, G - NHM 42609-2, dorsal (F) and lateral (G) views (internal mould of an exoskeleton); H - NMP L15605, ventral view (internal mould of a rostral plate); I - CGS JV10407, ventral view (internal mould of a rostral plate); J - JV 2297, ventral view (internal mould of a hypostome). Scale bars $=5 \mathrm{~mm}$ except in $\mathrm{H}-\mathrm{J}(=2 \mathrm{~mm})$. 

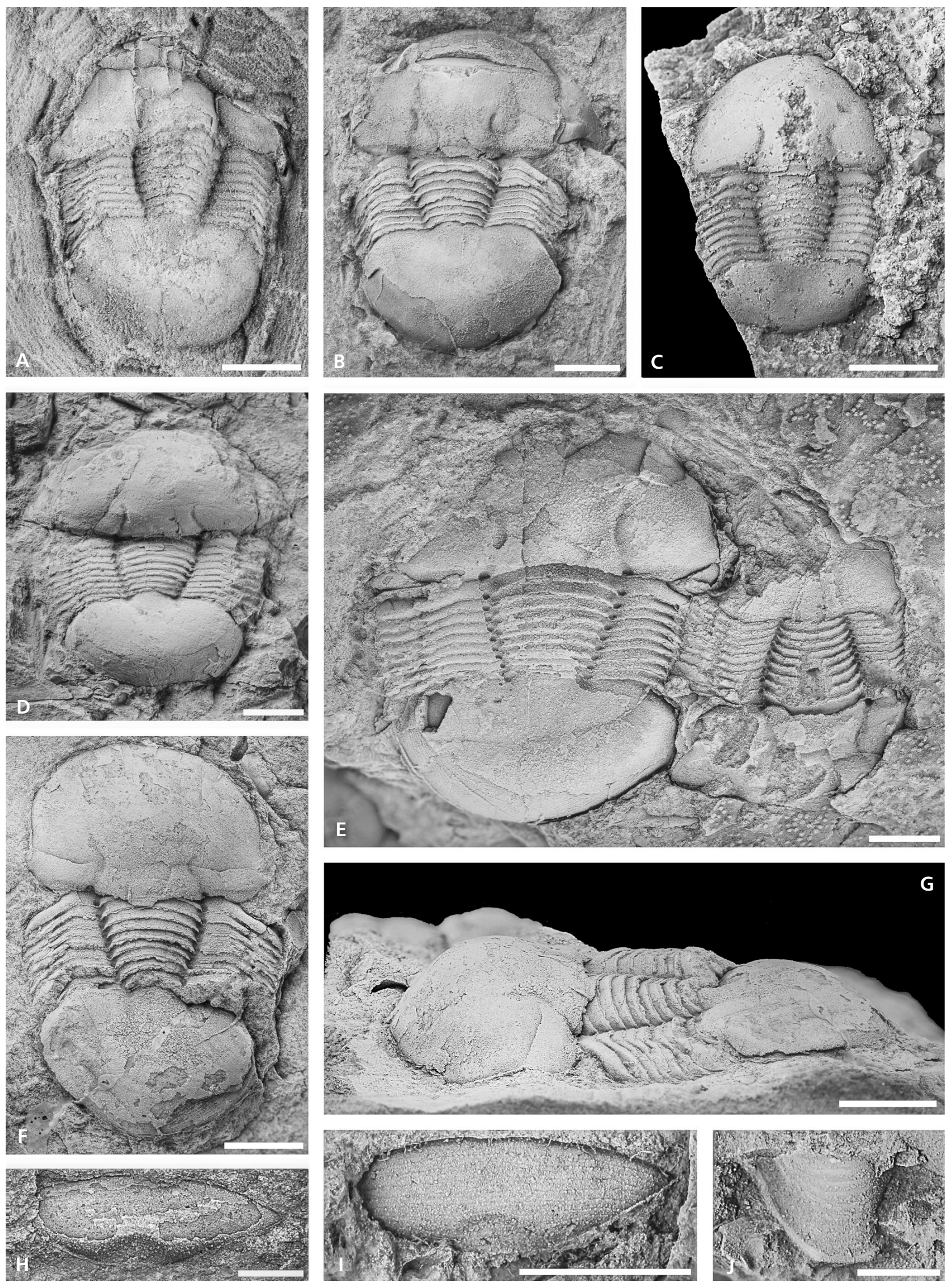
to other species of the genus. Previous records of Vysocania in the lower Berounian Libeň and Letná formations were assigned to $V$. panderi by Šnajdr (1957) and Bruthansová (2003). However, Jiří Vaněk, in a late stage of his career, considered that specimens from Libeň represent a new species, which he named 'Stenopareia vespertilio' nomen nudum - on the labels of his collection housed in the Česká geologická služba in Prague. This name was not included in the trilobite indexes published by Vaněk \& Valíček (2001, 2006), but it certainly corresponds to the new genus and new species suggested by Moravec (2002), but never validly erected, Harrisia rumpalensis - nomina nuda. On the other hand, the specimens from the Letná Formation were named as Harrisia omega Moravec nomina nuda - (Vaněk \& Valíček 2001). In this work, we revised the collections of those authors and other Vysocania specimens from the Libeň and Letná formations and we consider all of the material to be conspecific, the only difference being the slightly larger size of specimens from the latter unit.

Vysocania moraveci differs from the stratigraphically younger $V$. panderi in having a pointed genal angle (Fig. 6I; in V. panderi it is rounded), lower pygidial length/width ratio (55-65\% instead of $65-70 \%$ in $V$. panderi), ogival pygidial posterior margin (in $V$. panderi it is semicircular) and relatively longer pygidial axis (50\% of pygidial length, instead of $35-40 \%$ ).

\section{Vysocania panderi (Barrande, 1852)}

Figures 7, 8A-K

partim 1852 Illaenus panderi; Barrande, pp. 682-683, pl. 30, figs 4-9; pl. 35, figs 21-25 [non pl. 30, figs 10, $11=$ Octillaenus hisingeri].

partim 1957 Stenopareia panderi. - S̆najdr, pp. 160-166, text-figs 3, 7; pl. 7, figs 4-7 [non pl. 7, fig. $3=$ V. moraveci sp. nov.].

2001 Vysocania (?) vanessa Moravec (MS). - Vaněk \& Valíček, p. 34 [nomen nudum].

partim 2003 Stenopareia panderi. - Bruthansová, pp. 178-180, fig. 11a-c.

For a complete synonymy see Šnajdr (1957, p. 160).
Lectotype. - Designated by Šnajdr (1957); internal mould of a complete exoskeleton (NMP L15607, figured by Barrande 1852, pl. 35, fig. 21 and Bruthansová 2003, fig. 11a).

Type horizon and locality. - Zahořany Formation, middle Berounian ( $c a$. upper Sandbian/lower Katian), Zahořany, Czech Republic.

Material. - Vinice Formation: three exoskeletons (NMP 35050-6-35050-8).

Zahořany Formation: ten exoskeletons (NHM 42609-1, 42609-2; NMP L15610, 46553; CD1112, 6465, 35050-2, 35050-4, 35050-5; CGS JV1682); one enrolled exoskeleton (NHM 42458-1); seven cephala (NHM42458-3; NMP 35050-3, L46555; CGS JV2288, JV2289, JV2735, JV10384); one cranidium (NMP 35050-1); one cephalothorax (CGS JV2737-2); five pygidia (NHM 42458-4; NMP L46556; CGS JV2737-1, JV10405, JV10428); three articulated rostral plate + hypostome (NMP L15605, L46554; CGS MS21); two rostral plates (NMP L15605; CGS JV10407); one isolated hypostome (CGS JV2297).

Diagnosis. - Cephalic axial furrows strongly curved, extending about $1 / 3$ of cranidial length; librigena with slightly rounded genal angle; pygidium with evenly curved posterior margin, length/width ratio high (from $65 \%$ to $70 \%$ ); maximum pygidial width across posterior limit of axis; axis parabolic, about $35-40 \%$ of pygidial length and $25 \%$ of maximum pygidial width, flat to slightly concave, axial furrows indistinct; doublure long (55-60\% of sagittal pygidial length), inner edge with a wide (tr.) forward deflection medially.

Remarks. - For detailed descriptions see Šnajdr (1957, pp. 160-166) and Bruthansová (2003; pp. 178, 179). Vysocania panderi differs from other species of the genus in having a broadly rounded anterior cranidial margin, a slightly rounded genal angle (the other species all have small genal spines or pointed genal angles) and longer (sag.) pygidium (higher length/width ratio). The pygidial length/width ratio varies from 0.65 to 0.70 (based on dozens of specimens). The 0.82 ratio indicated by Mergl \& Budil (2011) in the lectotype of $V$. panderi (NMP L15607) is certainly due to deformation, to longitudinally stretched specimens.

Figure 8. A-K - Vysocania panderi (Barrande, 1852) from Zahořany Formation, middle Berounian (upper Sandbian/lower Katian), Czech Republic; A - NMP L46554, ventral view (internal mould of a cephalon with hypostome); B - NHM 42458-1, ventral and dorsal views (internal mould of an enrolled exoskeleton, detail of the cephalic doublure and the fragmentary pygidium); C - NHM 42458-3, lateral view (internal mould of a cephalon); D, E, F - NMP 35050, dorsal (D), lateral (E) and anterior (F) views (internal mould of a cranidium); G - CGS JV2289, oblique view (internal mould of a cephalon); H - NMP L46555, dorsal view (internal mould of a cephalon); I - NMP L46556, dorsal view (composite mould of apygidium); J - NHM I3410, posterodorsal view of pygidium (internal mould of an enrolled exoskeleton); K - NHM It13240, dorsal view (composite mould of a pygidium). - L-N - Vysocania sp. from the Huerva Member, Fombuena Formation, middle Berounian (upper Sandbian/lower Katian), Zaragoza, Spain; L - MPZ 2016/121, dorsal view (internal mould of an exoskeleton); M, N - MPZ 2016/123, lateral (M) and dorsal (N) views (internal mould of a cranidium). All scale bars $=5 \mathrm{~mm}$. 
Sofia Pereira et al. - The illaenid trilobites Vysocania and Octillaenus from the Upper Ordovician
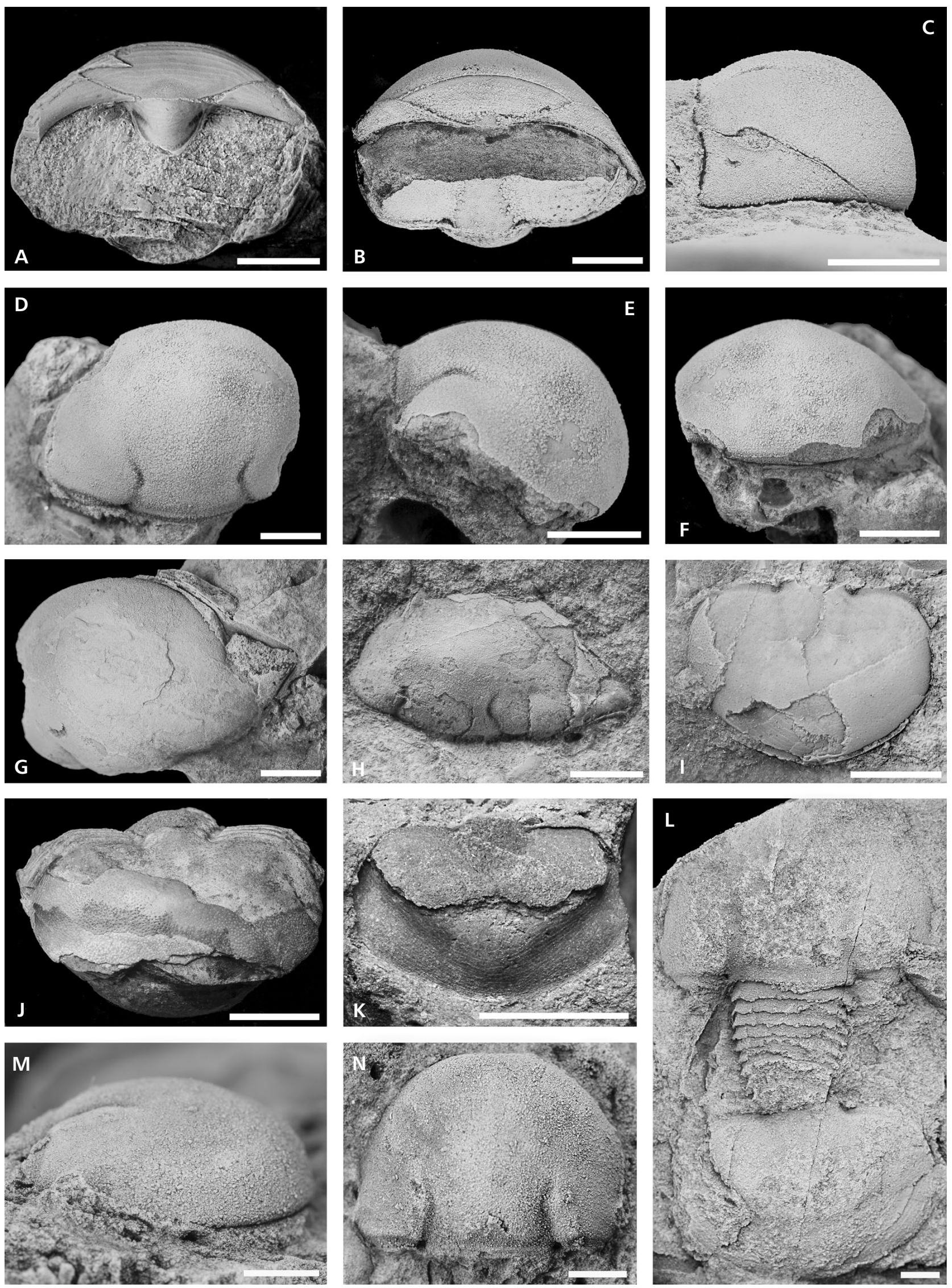
Specimens of Vysocania are rare in the middle Berounian Vinice Formation and were previously assigned to a new species by Moravec, who named it Vysocania (?) vanessa - nomen nudum - (Vaněk \& Valíček 2001). However, the specimens from this formation agree in morphology with those of $V$. panderi from the overlying Zahořany Formation, and consequently are here assigned to that species. Specimens from the Liben and Letná formations previously assigned to $V$. panderi (e.g. Barrande 1852, Šnajdr 1957, Bruthansová 2003) are here included in $V$. moraveci.

\section{Vysocania sp.}

Figure 8L-N

1978 Dysplanus (Zetillaenus)? sp. - Kolb, pl. 1, figs 11, 12.

Material. - Fombuena Formation (Zaragoza, Spain): one exoskeleton (internal mould: MPZ 2016/121a; external mould: MPZ 2016/121b); two cranidia as counterpart moulds (MPZ 2016/122a, 2016/123a, 2016/122b, 2016/123b).

Remarks. - The specimens show the diagnostic features of Vysocania iberica, except that one dorsal exoskeleton with the right librigena attached seems to have a rounded genal angle (Fig. 8L, observed in the external mould). Additional material from the Fombuena Formation, not examined for this study, also lacks a genal spine (Samuel Zamora, personal communication 2016). Further sampling in this region may clarify the species assignment. The specimens from the Fombuena Formation are among the largest known for the genus, reaching $60 \mathrm{~mm}$ in length.

Occurrence. - Huerva Member, Fombuena Formation, Fombuena (see Zamora et al. 2014), middle Berounian (upper Sandbian/lower Katian), Zaragoza, Spain.

\section{Genus Octillaenus Salter, 1867}

Type species. - Illaenus hisingeri Barrande, 1846, Králův Dvůr Formation, Kralodvorian (ca. global Ka3-4 stage slices, upper Katian), Czech Republic.

Diagnosis. - Cranidium semi-circular in outline, very convex (sag. and tr.); glabella corset-shaped, comprising
45-50\% of cranidial width posteriorly; axial furrows up to $60 \%$ of cranidial length; palpebral lobes of small to moderate size, located about half their own length from posterior margin of cranidium; librigena subtrapezoidal, longer (exsag.) than wide (tr.), with a short genal spine; thorax of eight segments, with narrow axis (approx. $40 \%$ of thoracic width anteriorly); rostral plate subtrapezoidal, with a length/width ratio about $30 \%$, oblique and almost straight connective sutures (diverging about $70^{\circ}$ to sagittal line) and a transverse posterior medial depression; pygidium subpentagonal to semicircular in outline, axis narrow $(25 \%$ of pygidial width anteriorly), defined mainly by deflection of anterior margin; pygidial doublure about $30 \%$ of pygidial length, inner margin with a short (sag.), forwardly directed cusp medially.

Other species. - Octillaenus marocanus sp. nov., Upper Ktaoua Formation, Kralodvorian ( $c a$. Ka4, upper Katian), Bou Ingarf (30 $\left.34^{\prime} 22^{\prime \prime} \mathrm{N} ; 5^{\circ} 34^{\prime} 20^{\prime \prime} \mathrm{W}\right)$, Zagora, Morocco.

Occurrence. - Upper Ordovician (upper Katian, Ka3-4; regional Kralodvorian) of Czech Republic and Morocco. Moreover, the genus was previously documented in Sweden, as Octillaenus hisingeri by Troedsson (1924) and in the United Kingdom as Octillaenus aff. hisingeri by Ingham (1970; pl. 3, figs 15-25), but it is not possible to confirm the generic assignment on the basis of the published illustrations.

\section{Octillaenus hisingeri (Barrande, 1846)}

Figure 9

1846 Illaenus hisingeri; Barrande, p. 14.

1852 Illaenus hisingeri. - Barrande, p. 681, pl. 29, figs 25-29.

1872 Illaenus oblitus. - Barrande, p. 73, pl. 15, figs 44, 45.

1957 Octillaenus hisingeri. - Šnajdr, pp. 155-159, pl. 7, figs $1,2$.

1957 Stenopareia oblita. - Šnajdr, pp. 166-169, pl. 7, figs 8-10.

1980 Octillaenus hisingeri. - Přibyl \& Vaněk, pp. 270, 271, pl. 2, figs 3-5.

2000 Octillaenus hisingeri. - Shaw, p. 376, pl. 1, figs 3-5, $7,14$.

2000 Stenopareia oblita. - Shaw, pp. 376-377, pl. 1, figs $11-13,15$.

Figure 9. Octillaenus hisingeri (Barrande, 1846) from the Králův Dvůr Formation, Kralodvorian (upper Katian), Czech Republic; A - NMP L15163, dorsal view (internal mould of an exoskeleton); B - CGS JV1597a, dorsal view (internal mould of an exoskeleton); C - CGS JV1597b, dorsal view (internal mould of an exoskeleton with cephalon overlapping the thorax); D - CGS PB 2001, dorsal view (internal mould of an incomplete exoskeleton); E, F- NMP L32849, dorsal (E) and lateral (F) views (internal mould of a cephalon and composite mould of a pygidium); G - NMP 6-00, dorsal view 

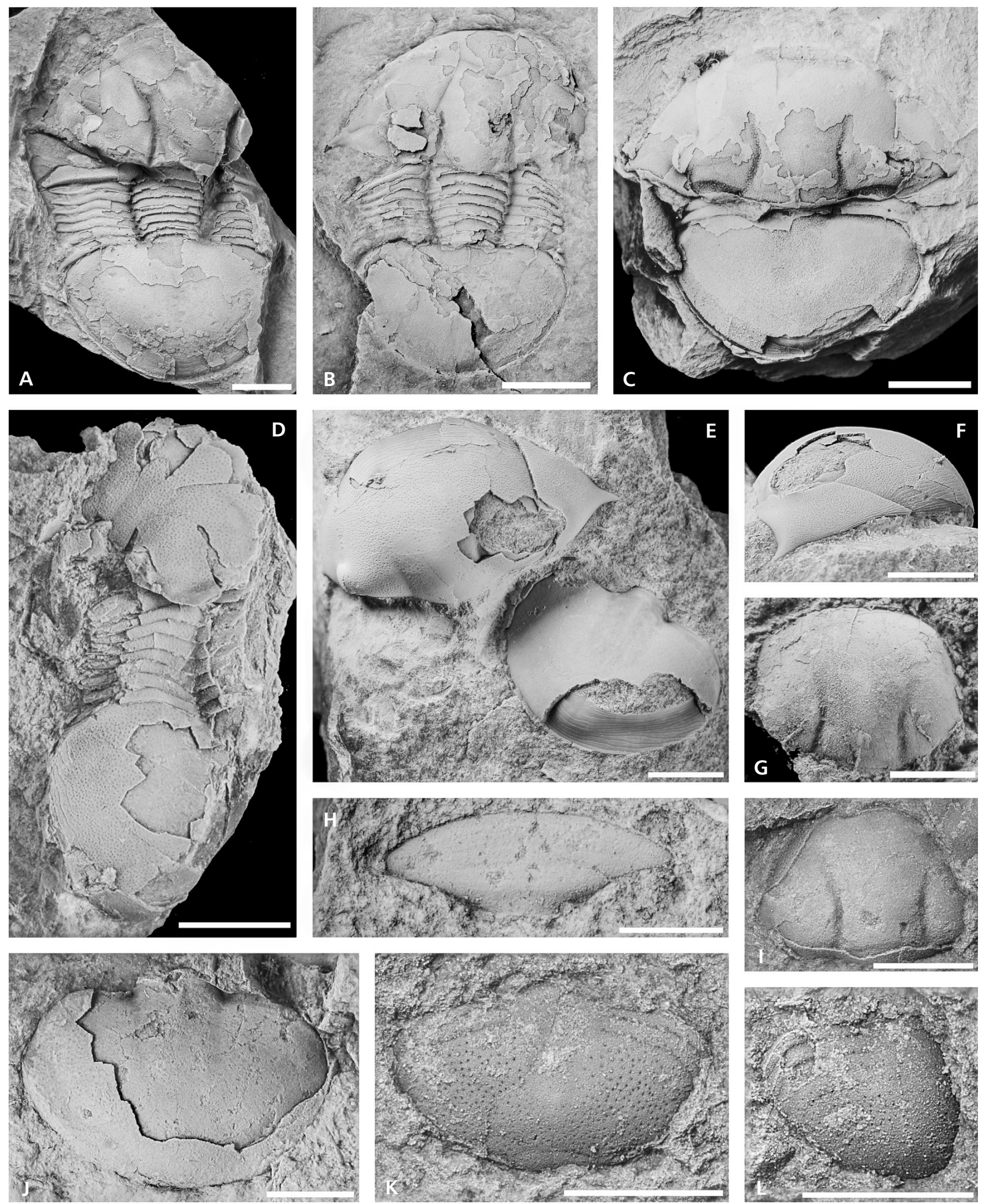

(internal mould of a cranidium); H - CGS JV9689, ventral view (internal mould of a rostral plate); I - CGS JV2743b-2, dorsal view (internal mould of a meraspis cranidium); J - CGS JV1641, dorsal view (internal mould of a pygidium); K - CGS JV2743a, dorsal view (internal mould of a meraspid pygidium, degree 6); L - CGS JV2743b-1, dorsal view (internal mould of a meraspis pygidium, degree 6?). Scale bar in A-G, J = $5 \mathrm{~mm}$; in $\mathrm{H}-\mathrm{I}, \mathrm{K}-\mathrm{L}=2 \mathrm{~mm}$. 
2003 Octillaenus hisingeri. - Bruthansová, pp. 175, 176, figs $8 \mathrm{a}, \mathrm{b}, \mathrm{d}$.

2003 Stenopareia oblita. - Bruthansová, p. 180, fig. $12 \mathrm{a}-\mathrm{e}$.

2009 Stenopareia oblita. - Fatka \& Mergl, p. 88, fig. 12c. For a complete synonymy list see Šnajdr (1957, pp. 155, 156, 166) and Bruthansová (2003; pp. 175, $176,180)$.

Lectotype. - Designated by Šnajdr (1957, p. 156); dorsal exoskeleton (NMP L15170, figured by Barrande 1852, pl. 29, figs 27, 28; Přibyl \& Vaněk 1980, pl. 2, fig. 3 and Shaw 2000, pl. 1, fig. 5).

Type horizon and locality. - Králův Dvůr Formation, Kralodvorian (ca. Ka4, upper Katian), Králův Dvůr, Beroun, Czech Republic.

Material. - Thirteen exoskeletons (CGS PB2001a, with counterpart 2001b, PB2002, L32844, L32845, L32846, L15163, L15169, L15173, L15163, L15169, L15171, L15173; CGS JV1597); one cephalon (NMP L32849); three cranidia (NMP 8-200, 6-00-1; CGS JV7588); one rostral plate (CGS JV9689); four pygidia (NMP 6-00-2, L32849; CGS JV2739-1, 2739-2); seven meraspides (cranidia: NMP A1-1, A1-2; CGS JV2743b-2; pygidium degree 7: NMP L33188, degree 6: CGS JV2743a, JV2743b-1, degree 5: CGS JV2743c).

Remarks. - 'Illaenus' oblitus was synonymized with Octillaenus hisingeri by Přibyl \& Vaněk (1980), Vaněk \& Vokáč (1997) and Vaněk \& Valíček (2001, 2006), but Hammann (1992), Shaw (2000) and Bruthansová (2003) rejected this synonymy. After identifying 'Stenopareia' cf. oblita in the Kralodvorian 'Caliza de Cistoideos' Formation from Spain, Hammann (1992) distinguished O. hisingeri and 'I.' oblitus based on the characters of the Spanish material, which is certainly neither conspecific nor congeneric with the Czech type material of 'I.' oblitus. The Spanish specimens, revised for this work, have smaller eyes, located further anteriorly, subtriangular librigenae with broadly rounded genal angle, very thick cuticle with coarser, deeper and denser pitting, more convex cranidial sagittal profile, longer pygidia with a strong pentagonal outline and the pygidial axis is segmented. For these reasons, we do not agree with Shaw (2000) that Hammann (1992) gave clear reasons why Přibyl \& Vaněk’s (1980) attempt to synonym- ize $O$. hisingeri and ' $I$.' oblitus was incorrect. For the present work, the type material and the classical collections of both $O$. hisingeri and 'I.' oblitus were revised and we consider this material to be conspecific. 'Illaenus' oblitus was erected and subsequently documented based on isolated sclerites from the upper part of the Králův Dvůr Formation, in dark grey shales and in the Perník (= Gingerbread) Bed (also named the 'pelocarbonate' bed), whereas $O$. hisingeri was defined and described based on prone or almost complete exoskeletons from underlying strata. However, the lectotype of 'I.' oblitus, designated by Šnajdr (1957) and figured by Barrande (1872, pl. 15, figs 44, 45), Přibyl \& Vaněk (1980, pl. 2, fig. 5), Shaw (2000, pl. 1, fig. 12) and Bruthansová (2003, fig. 12e), as well as other specimens figured as 'I.' oblitus from the Perník Bed (e.g. Shaw 2000, pl. 1, figs 11, 15; Bruthansová, 2003, fig. 12c), are indistinguishable morphologically from little-deformed specimens of $O$. hisingeri specimens (compare with Šnajdr 1957, pl. 7, fig. 1; Šnajdr 1990, p. 141), including in the presence of eight thoracic segments. Characters of $O$. hisingeri previously listed as differences from 'I.' oblitus (e.g. Barrande 1972, Šnajdr 1957, Hammann, 1992, Bruthansová 2003) are artefacts related to deformation. The palpebral lobes of isolated cranidia preserved as internal moulds seem smaller than when observed in complete cephala (compare cephala and isolated cranidia of Vysocania spp. or Octillaenus marocanus in this work), the longer cranidia and pygidia are typical of sagittally stretched and flattened specimens (compare Bruthansová 2003, fig. 8a and Šnajdr 1957, pl. 7, fig. 1 or Shaw 2000, pl. 1, fig. 7), and the club-shaped glabella, anteriorly defined in some specimens (see Barrande 1852, pl. 29, figs 25, 27; Bruthansová 2003 , fig. 8 b) is due to the compaction of the cephalon against the rostral plate and the cephalic doublure. Undeformed and permineralized specimens assigned to O. hisingeri (e.g. Bruthansová 2003, fig. 8d, here figured in Fig. 9E) show the cephalic and pygidial outlines and pitting typical of specimens of ' $I$.' oblitus from the Perník Bed. We therefore regard 'I.' oblitus as a junior synonym of $O$. hisingeri.

\section{Octillaenus marocanus sp. nov.}

Figures 10, 11A-E

1985 Stenopareia sp. - Destombes et al., p. 202.

? 2006 Octillaenus sp. - Destombes, pl. 40, fig. 7.

Figure 10. Octillaenus marocanus sp. nov. from Upper Ktaoua Formation, Kralodvorian (ca. upper Katian), Zagora, Morocco; A - MGM 6898X (holotype), dorsal view (internal mould of an exoskeleton); B - MGUTAD 15702, internal moulds of several specimens; C, D - MGM 6901X, dorsal (C) and anterior (D) views (latex cast of an external mould of a cranidium); E - MGM 6897X, oblique view (internal mould of a partially enrolled exoskeleton); F, G, H - MGUTAD 15602, dorsal (F), lateral (G) and anterior (H) views (internal mould of a cephalon); I, J - MGM 6903X, dorsal (I) and lateral (J) views (internal moulds of a cranidium); K - MGM 6904X, dorsal view (internal mould of a librigena). All scale bars = 5 mm. 

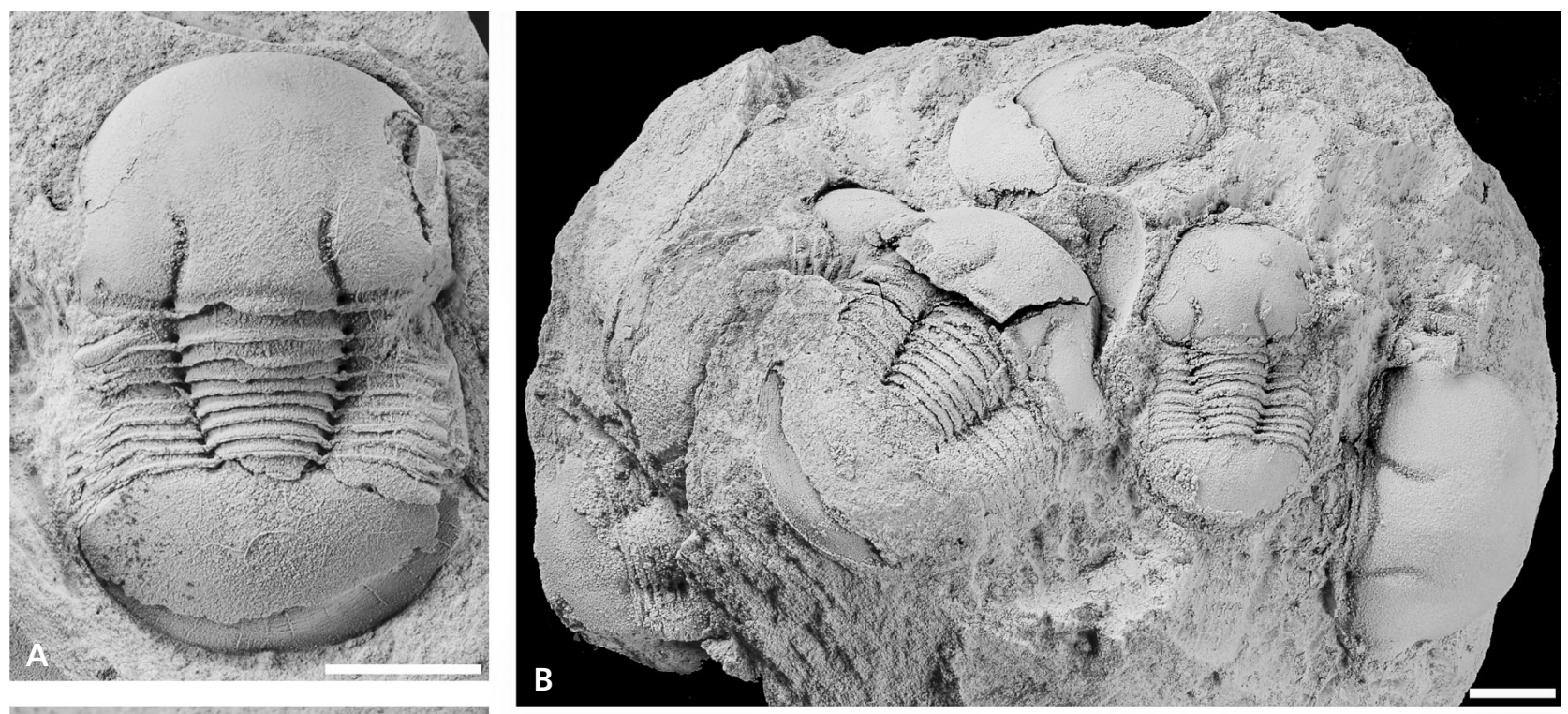
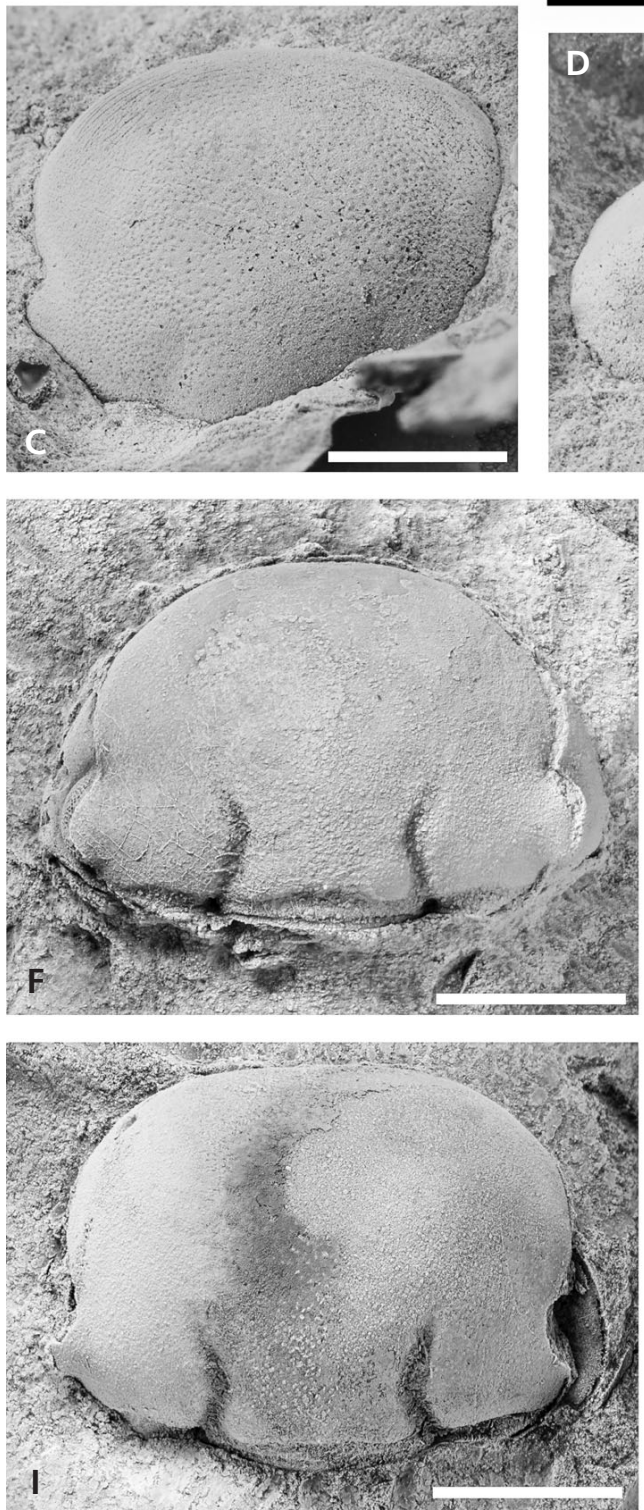
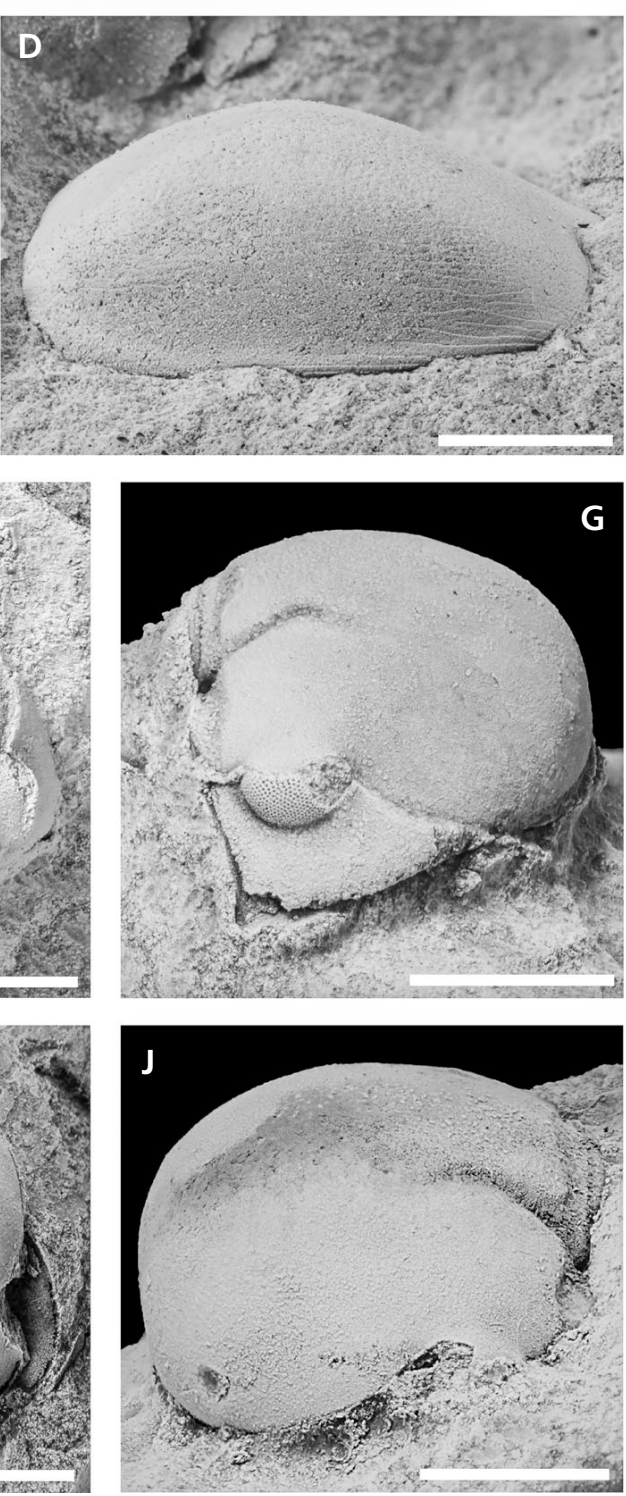
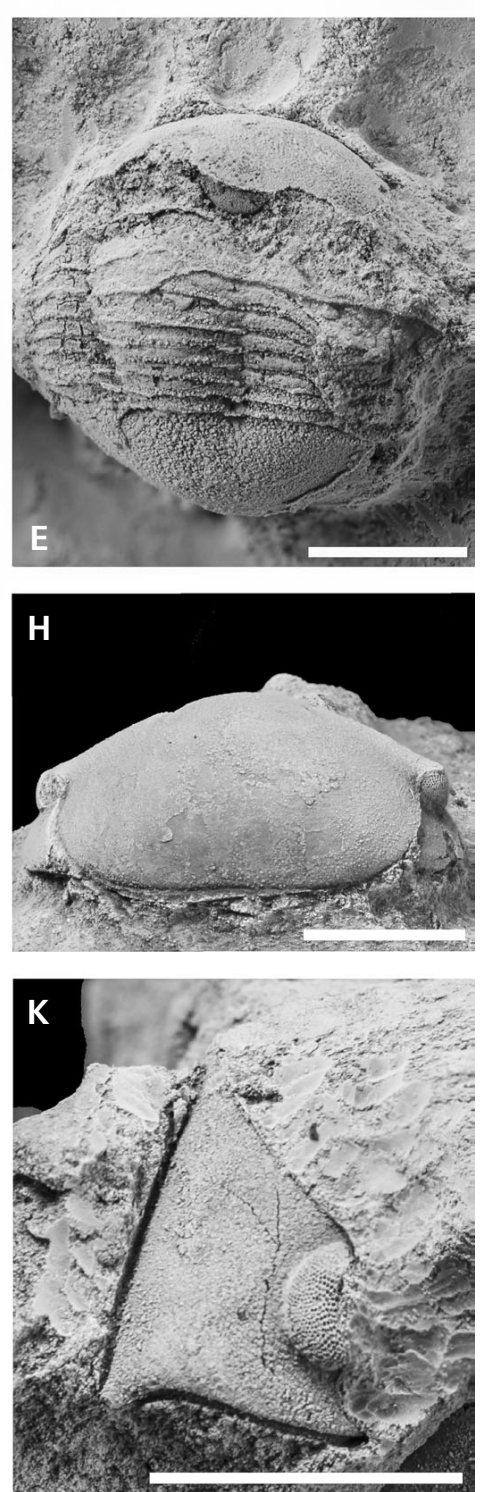
2010 Stenopareia aff. oblita. - Loi et al., p. 350.

2011 Stenopareia aff. oblita. - Legrand, p. 291.

2014 Octillaenus sp. - Rábano et al., p. 366.

Holotype. - Counterpart moulds of an exoskeleton lacking librigenae (MGM 6898Xa, 6898Xb; Fig. 10A).

Paratypes. - Four exoskeletons (MGM 6897X-1; MGUTAD 15701, 15702-1, 15702-2); two enrolled exoskeletons (MGM 6902X-2, 6912X); one cephalon (MGUTAD 15602); twenty-six cranidia (MGM 6895X-6907X, 6909X, 6914X-1, 6915X; MGUTAD 15602, 15700, 15702-3); one librigena (MGM 6904X-1); one rostral-plate (MGUTAD 15710-2); three thoracopyga (MGM 6895X-5, 6895X-6; MGUTAD 15702-4); six pygidia (MGM 6896X-2, 6896X-3, 6900X-1, 6910X, 6911X, 6914X-2; MGUTAD 15710).

Type horizon and locality. - Upper part of the Upper Ktaoua Formation; Kralodvorian ( $c a$. Ka4, upper Katian), Bou Ingarf ( $30^{\circ} 34^{\prime} 22^{\prime \prime} \mathrm{N}$; 5 $\left.34^{\prime} 20^{\prime \prime} \mathrm{W}\right)$, Zagora, Morocco.

Etymology. - After Morocco, from where the species is recorded.

Diagnosis. - Cranidium relatively short (sagittal length of $80 \%$ of width across palpebral lobes), extremely convex anteriorly in longitudinal profile; anterior margin slightly rounded; glabella about $45 \%$ of cranidial width posteriorly; axial furrows moderately curved, attaining about $35 \%$ of cranidial length; librigena subtrapezoidal with short genal spine; pygidium subelliptical to subpentagonal, with a low length/width ratio (about 58\%); axis almost parallel sided, about $50 \%$ of pygidial length and $25 \%$ of maximum pygidial width.

Description. - Cephalon semicircular; cranidium subquadrangular, strongly vaulted (sag. and tr.), overhanging anterior margin. Glabella corset-shaped, slightly higher than genal area in side view, width at posterior margin $45 \%$ of cranidial width. Axial furrows slightly longer behind lunette than in front, dying out abruptly; lunette situated opposite anterior edge of palpebral lobe $(\gamma)$. Occipital furrow broad (sag.), well defined on internal moulds, slightly convex anteriorly. Fixigenae broad (tr.), slightly narrower than glabella opposite lunette; posterior border furrow anteriorly arched, with depth and length similar to occipital furrow.
Posterior branch of facial suture very short (exsag.), exsagittal to convergent posteriorly; anterior branch divergent in posterior half, thereafter curving inwards (anterolateral cranidial corners broadly rounded). Palpebral lobes semi-circular, corresponding to $17 \%$ of cephalic length, located posteriorly (cranidial portion anterior to palpebral lobes corresponding to $66 \%$ of sagittal length); visual surface with dorsal lenses slightly larger than ventral ones. Librigenae subtrapezoidal, small, widest posteriorly, bearing a short, posterolaterally-directed genal spine; its external margin is continuous in outline with the librigenal lateral margin and forms an angle about $135^{\circ}$ with the posterior librigenal border; librigenal doublure narrow (tr.), bearing about eight straight terrace ridges subparallel to the librigenal margin. Dorsal surface of cranidium with sculpture of homogeneous and dense pits, sparser on glabella than on fixigena; pits interspersed anteriorly with sinuous and discontinuous terrace ridges (about 15) running subparallel to anterior margin but seldom preserved; librigenal doublure with about eight continuous terrace ridges subparallel to outer margins.

Thoracic morphology like that of Vysocania iberica; exoskeletal pitting significantly finer than cranidium and pygidium.

Pygidium with pleural facet oriented at about $35-40^{\circ}$ to sagittal line. Axial furrow not impressed; axis slightly convex (tr.), defined by forward deflection of anterior margin, change in convexity and muscle scars (rarely preserved). Dorsal surface except pleural facets with sculpture of pits as on cranidium, sparser on axis than on axial region, interspersed with sinuous and discontinuous terrace ridges abaxially and posteriorly; terrace ridges on pleural facets; doublure with about 15 uniformly spaced terrace ridges running subparallel to outer margin.

Remarks. - Octillaenus marocanus differs from the type-species $O$. hisingeri in having shorter (exsag.), more strongly curved cephalic axial furrows, a more convex (sag.) cephalon anteriorly, and a slightly shorter (sag.) pygidium (these two last differences may be exaggerated by deformation, but are supported by undeformed specimens of $O$. hisingeri, e.g. Fig. 9E). Although we were unable to verify that the first thoracic segment in O. marocanus is enlarged, as in $O$. hisingeri, one poorly preserved specimen suggests that it is (Fig. 10E). Although several specimens of $O$. marocanus were prepared to show the hypostome, it remains unknown.

Figure 11. A-E - Octillaenus marocanus sp. nov. from the Upper Ktaoua Formation, Kralodvorian (ca. upper Katian), Zagora, Morocco; A - MGUTAD 15710-2, ventral view (internal mould of a rostral plate); B - MGM 6900X-1b, dorsal view (latex cast of an external mould of a pygidium); C - MGM 6896X, dorsal and oblique views (internal moulds of a pygidium and a cranidium); D, E - MGUTAD 15710, dorsal (D) and lat- 

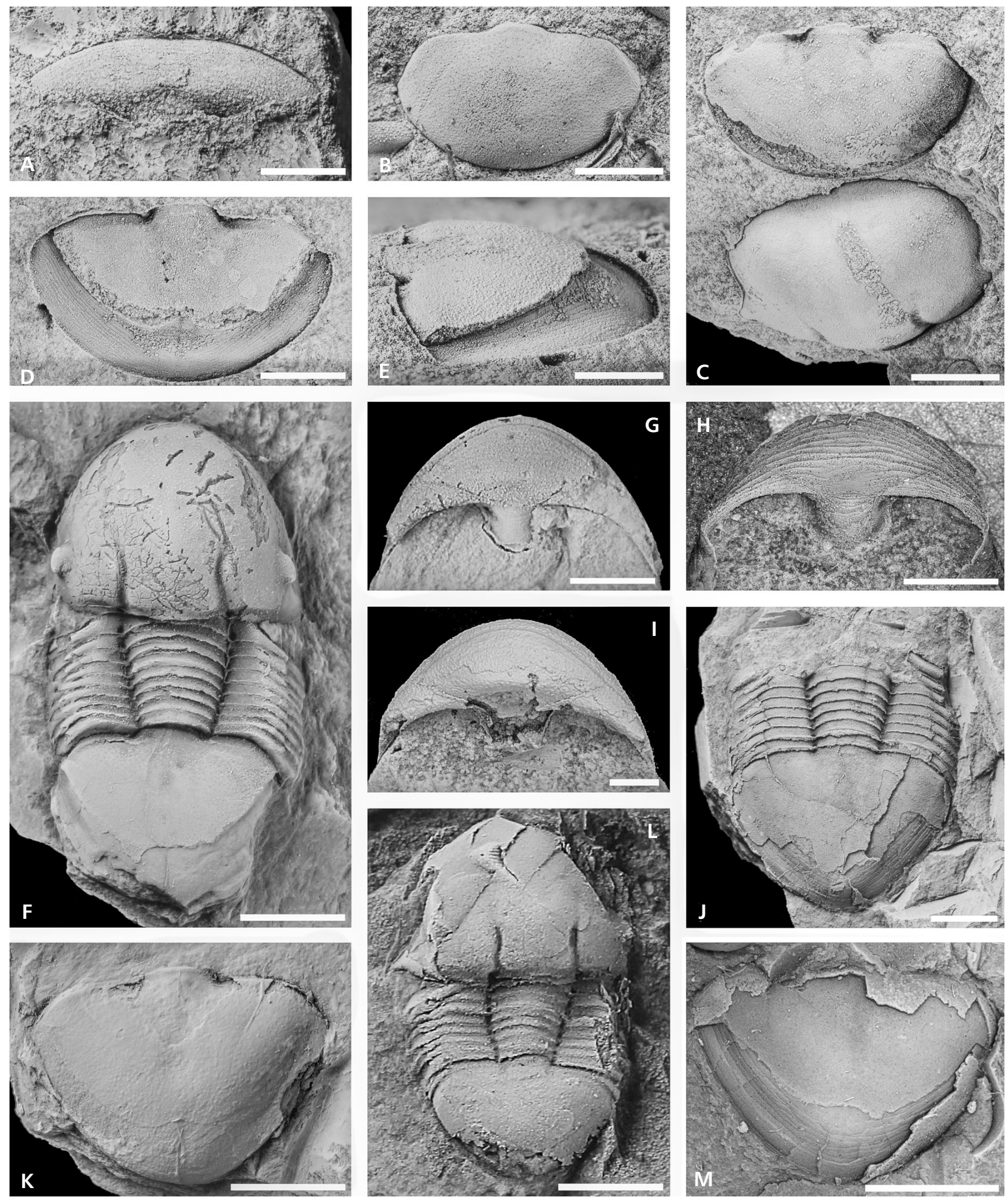

eral (E) views (composite mould of a pygidium). • F-M - Zetillaenus wahlenbergianus (Barrande, 1852) from the Králův Dvůr Formation, Kralodvorian (upper Katian), Czech Republic; F - NMP L32898, dorsal view (internal mould of an exoskeleton); G - CGS-MS-1, ventral view (internal mould of a cephalic doublure and hypostome); H, I - NMP L32891, ventral view (latex cast of external mould, H, and incomplete internal mould, I, of a cephalon with hypostome); J - NMP L46558, dorsal view (internal mould of a thoracopygon); K - NMP 36675, dorsal view (internal mould of a pygidium); L - NMP L20412, dorsal view (internal mould of a meraspid exoskeleton, degree 8); M - NMP 40-99, dorsal view (composite mould of a pygidium). Scale bars $=5 \mathrm{~mm}$ except in I, M (= $2 \mathrm{~mm})$. 


\section{Biostratigraphy, palaeobiogeography and evolution}

Vysocania is an endemic genus from the high latitude peri-Gondwana realm (for Trilobita, the Dalmanitoidean realm, sensu Adrain et al. 2004), being recorded from the Czech Republic, Portugal, Spain and possibly France and restricted to the Berounian regional stage. The earliest known occurrence of the genus is that of Vysocania moraveci from the Sandbian (regional lower Berounian), in the Libeň Formation of the Czech Republic. This is the only documented occurrence in the lower Berounian, but it is likely that Vysocania is also represented among coeval Moroccan illaenid material from the Izzeguirene and Lower Ktaoua formations, which has been mentioned (e.g. Destombes et al. 1985, Horný 1997, Gutiérrez-Marco et al. 2003, Rábano et al. 2014) but not formally identified, described or figured. The youngest occurrence of Vysocania in the Czech Republic is that of $V$. vaneki from the upper Berounian Bohdalec Formation. In Ibero-Armorica, lower Berounian trilobite assemblages are characterized by low diversity (Henry 1980) and illaenids have not been documented in them. In Portugal and Spain, Vysocania first appears in the middle Berounian, in coeval units bounded by an oolitic ironstone horizon (Favaçal and Chôsavelha beds in Portugal; Young 1988 and Sá et al. 2005, respectively), represented by $V$. iberica, which ranges into the upper Berounian.

Vysocania is particularly dominant in basal ironstone horizons with low trilobite diversity. In the Czech Republic, the genus is present at the base of the Vinice Formation, in the Zdice-Nučice 'Horizon' where trilobites are rare, and in the low-diversity Karlík 'Horizon', at the base of the upper Berounian Bohdalec Formation, the type-horizon for Vysocania vaneki. In Portugal, V. iberica is dominant in the ironstone beds that mark the base of the middle Berounian Cabeço do Peão and Louredo formations (the Favaçal Bed) and in the upper Berounian-Kralodvorian Porto de Santa Anna Formation, where trilobites are extremely rare. Thus, species of Vysocania seem to have had a great capacity to adapt quickly to environmental change, with the competitive ability to occupy new biotopes. The abundance and broad geographic distribution of these species in the Berounian units of the high latitude peri-Gondwana realm lend them value as index fossils.

The study of abundant and well-preserved material of Octillaenus marocanus, together with the revision of the genus Vysocania, suggests that Octillaenus belongs to the same evolutionary lineage, developing through paedomorphic (neotenic) processes. Vysocania and Octillaenus share many of the same diagnostic features, and the only differences may be attributable to paedomorphism: eight instead of nine thoracic segments and a shorter pygidial doublure with a narrower and shorter anteromedial deflection. Paedomorphism, in particular neoteny but also hypomorphosis (progenesis), is common among trilobites (e.g. Hupé 1953; McNamara 1981, 1986 and references therein; Crônier 2013 and references therein). Meraspid transitory pygidia of Vysocania vaneki from the Bohdalec Formation show that the doublure is shorter (sag.) in juveniles than in holaspides (compare Figs $3 \mathrm{~K}-\mathrm{O}$ ). The same ontogenetic trend of an increase in the length of the pygidial doublure is shown by holaspides of $V$. iberica, with smaller specimens having shorter (sag.) doublures than larger ones (e.g. Hammann, 1976, pl. 3, fig 27a, and Fig. 4 herein). This trend may explain the typically shorter (sag.) pygidial doublure of $V$. vaneki, a species represented by small specimens, compared to the stratigraphically older species $V$. panderi. Alternatively, the shorter pygidial doublure of $V$. vaneki might be explained by an evolutionary trend in this character, similar differences in the length of the pygidial doublure being documented in other illaenid genera (e.g. Stenopareia glaber and the younger S. linnarssoni; compare Bruton \& Owen 1988, figs 9d and 10a, b). The generally smaller size of Octillaenus species compared to those of Vysocania, the shorter pygidial doublure and its similarities with the youngest Vysocania species in the Czech Republic (V. vaneki; compare Figs 3M and 11D), the presence of one less thoracic segment and the stronger pitted sculpture are characters typical of Vysocania meraspides. In addition, in some Vysocania specimens (e.g. V. iberica, Figs 3F, 4I, 5C) the first thoracic segment seems slightly longer (exsag.) than the remaining segments (not significantly, tr.). Thus, the macropleural condition of Octillaenus may be another juvenile character retained from its presumed ancestor Vysocania. Apart from the number of the thoracic segments, it is extremely difficult to distinguish Octillaenus and Vysocania; cephala and pygidia share the same dorsal features, and the rostral plate is similar.

Since relatively complete ontogenetic sequences are known for only a few members of the Illaenidae (e.g. Chatterton \& Ludvigsen 1976, Chatterton 1980), it is difficult to use developmental data in resolving problems in the systematic relationships and phylogeny of the group. Furthermore, certain characters currently regarded as of taxonomic significance (e.g. the configuration of the pygidial doublure) may be more dependent on ontogenetic variability, being affected by paedomorphic processes, rather than being unique synapomorphies.

The morphological similarity between Vysocania and other Stenopareia-like trilobites is here interpreted as due to homoeomorphy. Another example of this phenomenon within the Illaenidae is Eastonillaenus Edgecombe \& Webby, 2007 from the Katian (Eastonian of the Australian regional chart) of New South Wales. Eastonillaenus is very similar to Vysocania in the form of the cranidium, rostral plate and hypostome (see Edgecombe \& Webby 2007, 
figs $1 \mathrm{c}, 3 \mathrm{~b}, \mathrm{~d}, \mathrm{f}, \mathrm{g})$, but is clearly distinct in the thoracic and pygidial structure, having a very broad axis that gently tapers posteriorly. The similarity of both genera in ventral structure may also suggest that Vysocania is related to a geographically widely-dispersed clade of Illaenidae, including such genera as Parillaenus, Eastonillaenus and possibly Zetillaenus. Despite the previously documented differences between Zetillaenus (upper Katian) and Vysocania (Sandbian-lower Katian), both taxa have several characters in common, including not only the general dorsal morphology (e.g. axial furrows, occipital and fixigenal posterior furrows, genal spines, position of the eyes, facial sutures, axial width) but also some ventral features, namely the pygidial doublure and the hypostome (the only difference in the latter being the distinct shoulders in Zetillaenus).

After the works of Jaanusson (1954), Lane \& Thomas (1983) and Whittington (1997), the need for a comprehensive revision of the Illaenidae incorporating both dorsal and ventral characters became evident. The lack of information on the ventral morphology of many illaenids is one of the major impediments to improve the revision of this family.

\section{Conclusions}

Vysocania is an independent genus distinguishable from Stenopareia and Zetillaenus and endemic to the high latitude peri-Gondwanan realm. Three previously named species are here included in Vysocania: 'Zbirovia' vaneki Šnajdr, 1958, the type-species, 'Dysplanus (Zetillaenus)' ibericus Hammann, 1976 and 'Illaenus' panderi Barrande, 1852. One new species is erected, V. moraveci from the Upper Ordovician of the Czech Republic. 'Illaenus' oblitus Barrande, 1872 is synonymized with Octillaenus hisingeri (Barrande, 1846), the type-species of Octillaenus, and the new species $O$. marocanus, from the Upper Ordovician of Morocco, is erected. Octillaenus is considered to have arisen from Vysocania through paedomorphic (neotenic) processes. From an ecological point of view, species of $V y$ socania seem to have had good adaptability to environmental changes and the competitive ability to occupy new biotopes, as a result being particularly dominant in the low trilobite diversity palaeoenvironments recorded in Ordovician ironstone horizons.

\section{Acknowledgements}

We thank M. Ramalho (Museu Geológico de Lisboa), J. Ignacio (Universidad de Zaragoza), J. Anger (Senckenberg Museum, Frankfurt am Main), C. Mellish (National History Museum, London) and P. Kraft (Muzeum Dr. Bohuslava Horáka v Roky- canech) for granting access to fossil collections under their care; J. Colmenar (Natural History Museum of Denmark, Copenhagen) for assisting in fieldwork in Portugal, Spain and Morocco; J. Álvaro (Instituto de Geociencias, CSIC-UCM, Madrid) and S. Lorenzo (Universidad de Castilla-La Mancha, Ciudad Real) for assisting in fieldwork in Morocco; S. Zamora (Instituto Geológico y Minero de Espańa, Madrid) for his help with Fombuena Formation material; A. Cravinho Santos (Universidade de Lisboa) for assisting with some images and formatting details; J. C. Gutiérrez-Marco (CSIC-Spanish National Research Council, Madrid) for facilitating access to MGM specimens; Martin David (Prague) for fruitful discussions on Králův Dvůr Formation specimens; and J. Adrain (University of Iowa, Iowa City) for helpful discussions on various matters. We thank David Bruton (Natural History Museum, University of Oslo) for revision and suggestions. We specially thank D. Holloway (Museums Victoria) for valuable revisions, discussion and suggestions that allowed us to significantly improve our manuscript. SP is supported by a FCT PhD grant (SFRH/BD/73722/2010) and a SYNTHESYS (Synthesis of Systematic Resources) grant (CZ-TAF-4786). AAS and IR are supported by the project CGL2012-39471 of the Spanish MINECO. PB was supported by the Czech Geological Survey internal project No. 339900. LL is supported by the Ministry of Culture of the Czech Republic (DKRVO 2016/06, National Museum, 00023272). This paper is a contribution to the International Geoscience Programme (IGCP) Project 653 - The Onset of the Great Ordovician Biodiversification Event (IUGS-UNESCO).

\section{References}

Adrain, J.M., Edgecombe, G.D., Fortey, R.A., Hammer, Ø., Laurie, J.R., McCormick, T., Owen, A.W., Waisfeld, B.G., Webby, B.D., Westrop, S.R. \& Zhou, Z.Y. 2004. Trilobites, 231-254. In Webby, B.D., Paris, F., Droser, M.L. \& Percival, I.G. (eds) The Great Ordovician Biodiversification Event. Columbia University Press, New York.

Álvaro, J.J., Vennin, E., Villas, E., Destombes, J. \& Vizcaïno, D. 2007. Pre-Hirnantian (latest Ordovician) benthic community assemblages: controls and replacements in a siliciclastic-dominated platform of the eastern Anti-Atlas, Morocco. Paleogeography, Paleoclimatology, Palaeocology 251(1), 20-36. DOI 10.1016/j.palaeo.2005.09.035

Babin, C. \& Darboux, J.R. 1982. Feuille Le Faou. Carte géologique de la France à 1:50,000, 275, 46 pp.

BARRANDE, J. 1846. Notice préliminaire sur le Systême silurien et les trilobites de Bohême. 97 pp. Hirschfeld, Leipzig.

DOI 10.5962/bhl.title.9142

BARRANDE, J. 1852. Systême silurien du centre de la Bohême. Ière Partie. Recherches paléontologiques. 1. Crustacés: Trilobites. 935 pp. Privately published, Prague \& Paris. DOI 10.5962/bhl.title.82327

BARRANDE, J. 1872. Systême silurien du centre de la Bohême. lère partie: Recherches paléontologiques. Supplément au Vol. 1. Trilobites, crustacés divers et poissons. 647 pp. Privately published, Prague \& Paris. 
Bergström, S.M., Chen, X., Gutiérrez-Marco, J.C. \& Dronov, A.V. 2009. The new chronostratigraphic classification of the Ordovician System and its relations to major regional series and stages and to $\delta^{13} \mathrm{C}$ chemostratigraphy. Lethaia 42(1), 97-107.

DOI 10.1111/j.1502-3931.2008.00136.x

BruthansovÁ, J. 2003. The trilobite family Illaenidae Hawle et Corda, 1847 from the Ordovician of the Prague Basin (Czech Republic). Transactions of the Royal Society of Edinburgh, Earth Sciences 93, 167-190. DOI 10.1017/S0263593300000407

Bruton, D.L. \& OwEn, A.W. 1988. The Norwegian Upper Ordovician illaenid trilobites. Norsk geologisk Tidsskrift 68, 241-258.

Budil, P., Fatka, O., Kolár̆, P. \& David, M. 2011. Arthrorhachis Hawle \& Corda, 1847 (Agnostida) in the Prague Basin (Barrandian area, Czech Republic) revisited. Bulletin of Geosciences 86(4), 707-724. DOI 10.3140/bull.geosci.1262

Carlucci, J., Westrop, S.R., Amati, L., Adrain, J.M. \& Swisher, R.E. 2012. A systematic revision of the Upper Ordovician trilobite genus Bumastoides (Illaenidae), with new species from Oklahoma, Virginia and Missouri. Journal of Systematic Palaeontology 10, 679-723.

DOI 10.1080/14772019.2011.637518

Chatterton, B.D.E. 1980. Ontogenetic studies of Middle Ordovician trilobites from the Esbataottine Formation, Mackenzie Mountains, Canada. Palaeontographica, Abteilung A 171, $1-74$.

Chatterton, B.D.E. \& Ludvigsen, R. 1976. Silicified Middle Ordovician trilobites from the South Nahanni River area, District of Mackenzie, Canada. Palaeontographica, Abteilung A 154, 1-106.

CRÔNIER, C. 2013. Morphological disparity and developmental patterning: contribution of phacopid trilobites. Palaeontology 56(6), 1263-1271. DOI 10.1111/pala.12024

Delgado, J.F.N. 1908. Système silurique du Portugal. Étude de stratigraphie paléontologique. 245 pp. Memórias da Commissão dos Serviços geologicos de Portugal, Lisbon.

Destombes, J. 2006. Carte géologique au 200000 de l'Anti-Atlas marocain. Paléozoïque inférieur. Cambrien moyen et supérieur-Ordovicien-base du Silurien. Sommaire général sur les Mémoires explicatifs des cartes géologiques au 1/200 000 de l'Anti-Atlas marocain. Notes et Mémoires du Service Géologique du Maroc 515, 1-149.

Destombes, J., Hollard, H. \& Willefert, S. 1985. Lower Palaeozoic rocks of Morocco, 91-336. In Holland, C.H. (ed.) Lower Palaeozoic rocks of the World, vol. 4. Lower Palaeozoic of north-western and west central Africa. John Wiley and Sons, Chichester.

Edgecombe, G.D. \& WebBy, B.D. 2007. Ordovician trilobites with eastern Gondwanan affinities from central-west New South Wales and Tasmania. Memoirs of the Association of Australasian Palaeontologists 34, 255-281.

FatKa, O. \& Mergl, M. 2009. The "microcontinent" Perunica: status and story 15 years after conception, 65-102. In BASSETT,
M.J. (ed.) Early Palaeozoic peri-Gondwanan terranes: new insights from tectonics and biogeography. Geological Society of London, Special Publications 325.

Fatka, O, Lerosey-Aubril, R., Budil, P. \& RaK, Š. 2013. Fossilised guts in trilobites from the Upper Ordovician Letná Formation (Prague Basin, Czech Republic). Bulletin of Geosciences 88(1), 95-104. DOI 103140/bull.geosci.1329

Gutiérrez-Marco, J.C. \& Rábano, I. 1987. Trilobites y graptolitos de las lumaquelas terminales de los "Bancos Mixtos" (Ordovícico Superior de la zona Centroibérica meridional): Elementos nuevos o poco conocidos. Boletín Geológico y Minero 98, 647-669.

Gutiérrez-Marco, J.C., Destombes, J., Aceñolaza, F.G., Sarmiento, G.N., Rábano, I. \& San José, M.A. de 2003. El Ordovícico Medio del Anti-Atlas marroquí: paleobiodiversidad, actualización bioestratigráfica y correlación. Geobios 36(2), 151-177. DOI 10.1016/S0016-6995(03)00004-4

Gutiérrez-Marco, J.C., Sá, A.A., García-Bellido, D. \& RÁBANO, I. 2017. The Bohemo-Iberian regional chronostratigraphic scale for the Ordovician System and palaeontological correlations within South Gondwana. Lethaia 50, 258-295. DOI 10.1111/let.12216

Hammann, W. 1976. Trilobiten aus dem oberen Caradoc der östlichen Sierra Morena (Spanien). Senckenbergiana lethaea 57(1), 35-85.

HammanN, W. 1992. The Ordovician trilobites from the Iberian Chains in the Province of Aragón, NE Spain. 1. The trilobites of the Cystoid Limestone (Ashgill Series). Beringeria 6, $1-219$.

Hammann, W. \& Leone, F. 1997. Trilobites of the post-Sardic (Upper Ordovician) sequence of southern Sardinia. Part 1. Beringeria 20, 1-217.

Hammann, W., Robardet, M. \& Romano, M. 1982. The Ordovician System in southwestern Europe (France, Spain, and Portugal). Correlation chart and explanatory notes. International Union of Geological Sciences Publication No. 11, 1-47.

Havlíček, V. 1998. Ordovician, 41-79. In Chlupáč, I., HavlíčeK, V., KŘižz, J., KuKal, Z. \& ŠTorCh, P. (eds) Palaeozoic of the Barrandian (Cambrian to Devonian). Czech Geological Survey, Prague.

HAVLIČEK, V. \& VANĚK, J. 1966. The biostratigraphy of the Ordovician of Bohemia. Sborník geologických věd, Paleontologie 8, 7-69.

Hawle, I. \& CoRda, A.J.C. 1847. Prodrom einer Monographie der böhmischen Trilobiten. 176 pp. J.G. Calve, Prague. [Reprinted in 1848 in Abhandlungen der königlichen böhmischen Gessellschaft der Wissenschaften 5, 117-292.]

Henry, J.L. 1980. Trilobites ordoviciens du Massif Armoricain. Mémoires de la Société géologique et minéralogique de Bretagne 22, 1-250.

HoLm, G. 1886. Revision der ostbaltischen silurischen Trilobiten, von Fr. Schmidt. Abtheilung 3. Illaeniden. Mémoires de l'Académie impériale des Sciences de St-Pétersbourgh, Series $7,33(8), 1-173$.

HoRnÝ, R.J. 1997. Ordovician Tergomya and Gastropoda 
(Mollusca) of the Anti-Atlas (Morocco). Acta Musei Nationalis Pragae, Series B, Natural History 53, 37-78.

HuPÉ, P. 1953. Classification des trilobites. Annales de Paléontologie 39, 61-168.

InGHAM, J.K. 1970. A monograph of the upper Ordovician Trilobites from the Cautley and Dent districts of Westmorland and Yorkshire. Part 1. Palaeontographical Society Monograph 124(526), 1-58.

JAAnusson, V. 1954. Zur Morphologie und Taxonomie der Illaeniden. Arkiv för Mineralogi och Geologi 1, 545-583.

JAANUSSON, V. 1959. Suborder Illaenina Jaanusson nov., 365. In Moore, R.C. (ed.) Treatise on invertebrate paleontology. Part O. Arthropoda 1. Geological Society of America \& University of Kansas Press, Lawrence.

Kobayashi, T. 1935. The Cambro-Ordovician formations and faunas of South Chosen. Palaeontology, Part 3. Cambrian faunas of South Chosen with a special study on the Cambrian trilobite genera and families. Journal of the Faculty of Science, University of Tokyo, Section 2, Geology, Mineralogy, Geography, Geophysics 4(2), 49-344.

Kolb, S. 1978. Erläuterung zur geologischen Kartierung des Gebietes S Cerveruela in den östlichen Iberischen Ketten (NE-Spanien). 122 pp. Ph.D. thesis, Paläontologisches Institut der Universität Würzburg, Würzburg, Germany.

Kraft, P., Štorch, P. \& Mitchell, C.E. 2015. Graptolites of the Králův Dvůr Formation (mid Katian to earliest Hirnantian, Czech Republic). Bulletin of Geosciences 90(1), 195-225. DOI 10.3140/bull.geosci.1435

Lane, P.D. \& Thomas, A.T. 1983. A review of the trilobite suborder Scutelluina. Special Papers in Palaeontology 30, 141-160.

Legrand, P. 2011. On the Katian/Hirnantian boundary. Application on the north-African border of Gondwana, 287-294. In GutiérRez-Marco, J.C., RÁBAno, I. \& García-Bellido, D. (eds) Ordovician of the World. Cuadernos del Museo Geominero 14. Instituto Geológico y Minero de España, Madrid, Spain.

Loi, A., Ghienne, J.F., Dabard, M.P., Paris, F., Botquelen, A., Christ, N., Elaouad-Debbaj, Z., Gorini, A., Vidal, M., Videt, B. \& Destombes, J. 2010. The Late Ordovician glacio-eustatic record from a high-latitude storm-dominated shelf succession: The Bou Ingarf section (Anti-Atlas, Southern Morocco). Palaeogeography, Palaeoclimatology, Palaeoecology 296, 332-358. DOI 10.1016/j.palaeo.2010.01.018

McNamara, K.J. 1981. Paedomorphosis in middle Cambrian xystridurine trilobites from northern Australia. Alcheringa 5, 209-224. DOI 10.1080/03115518108567002

McNamara, K.J. 1986. A guide to the nomenclature of heterochrony. Journal of Palaeontology 60(1), 4-13. DOI 10.1017/S0022336000021454

Mergl, M. \& Budil, P. 2011 Unikátní zachování exoskeletonů trilobitů $\mathrm{v}$ řevnických křemencích (libeňské souvrství, ordovik) z Ejpovic na Rokycansku. Zprávy o geologických výzkumech v roce 2010, 109-112.

Moravec, J.K. 2002. Rokycanská Čílina-Sloupy, nová lokalita $\mathrm{v}$ řevnických křemencích libeňské souvrství v jihozápadním křídle pražské pánve (Beroun). Zprávy o geologických výzkumech v roce $2001,55-56$.

Owen, A. W. \& Bruton, D. L. 1980. Late Caradoc-early Ashgill trilobites of the central Oslo Region, Norway. Palaeontological Contributions from the University of Oslo No. 245, 1-63.

Owens, R.M. \& Servais, T. 2007. The Ordovician of the Condroz Ridge, Belgium. Palaeogeography, Palaeoclimatology, Palaeoecology 245, 272-294.

DOI 10.1016/j.palaeo.2006.02.025

Pereira, S., SÁ, A.A., Silva, C.M. DA \& VAZ, N.M. 2015a. Trilobites of the Chão do Amieiral Formation (middle Berounian, Upper Ordovician) from Moncorvo, Portugal, 61-64. In Pereira, I. \& Silva, V. (eds) V Congresso Jovens Investigadores em Geociências. LEG 2015, Volume, Scientific Programme \& Abstracts.

Pereira, S., Silva, C.M. Da, Pires, M. \& Sá, A.A. 2015b. The oldest brachymetopid trilobite record from the European peri-Gondwana. Bulletin of Geosciences 90(3), 543-553. DOI 10.3140/bull.geosci.1535

Portero García, J.M., Ancochea, E., Gallardo, J. \& Pérez-González, A. 1988 (eds) Memoria explicativa del Mapa Geológico de España (MAGNA), Hoja n. ${ }^{\circ} 784$ (Ciudad Real). Instituto Geológico y Minero de España, Madrid.

PŘIBYL, A. \& VANĚK, J. 1980. Neue Erkenntnisse über einige Trilobiten aus dem böhmischen Ordovizium. C̆asopis pro mineralogii a geologii 25(3), 263-274.

RÁbano, I. 1984. Trilobites ordovícicos del Macizo Hespérico español: una visión bioestratigráfica. Cuadernos de Geología Ibérica 9, 267-287.

Rábano, I., Gutiérrez-Marco, J.C. \& García-Bellido, D.C. 2014. A remarkable illaenid trilobite from the Middle Ordovician of Morocco. Bulletin of Geosciences 89(2), 365-374. DOI 10.3140/bull.geosci.1467

Repina, L.N., Petrunina, Z.E. \& KhajRullina, T.I. 1975. Trilobites, 100-233. In Repina, L.N., Yaskovich, B.V., AKsarina, N.A., Petrunina, Z.E., Poniklenko, I. A., Rubanov, D.A., Bolgova, G.V., Golikov, A.N., KhajRullina, T.I. \& Posokhova, M.M. (eds) Stratigraphy and fauna of the Lower Paleozoic of the northern submontane belt of Turkestan and Alai Ridges (southern Tyan-Shan). Akademiya Nauk SSSR, Sibirskoe Otdelenie, Instituta Geologii i Geofiziki, Trudy 278, 1-351. [in Russian]

Romão, J.M.C. 2000. Estudo tectono-estratigráfico de um segmento do bordo $S W$ da Zona Centro-Ibérica, e as suas relações com a Zona Ossa Morena. 322 pp. Ph.D. thesis, University of Lisbon, Lisbon, Portugal.

Romão, J.M.C., Gutiérrez-Marco, J.C., RÁbano, I., Oliveira, J.T. \& Marques Guedes, A. 1995. A Formação Cabeço do Peão (Ordovícico Superior) no sinforma Amęndoa-Carvoeiro (SW da ZCI) e sua correlação estratigráfica na província mediterrânica. Memórias do Museu e Laboratório Mineralógico e Geológico da Faculdade de Ciências da Universidade do Porto 4, 121-126.

SÁ, A.A., Meireles, C., Coke, C. \& Gutiérrez-Marco, J.C. 2005. Unidades litoestratigráficas do Ordovícico da região de 
Trás-os-Montes (Zona Centro Ibérica). Comunicações Geológicas 92, 31-74.

Sá, A.A., Piçarra, J., Vaz, N., Sequeira, A. \& GutiérrezMarCo, J.C. 2011. Ordovician of Portugal. 1-79. In SÁ, A.A., Piçarra, J., Vaz, N., Sequeira, A. \& Gutiérrez-Marco, J.C. (eds) $11^{\text {th }}$ International Symposium on the Ordovician System, Pre-Conference Field Trip Guide.

SALTER, J.W. 1867. A monograph of the British trilobites from the Cambrian, Silurian and Devonian formations. Part 4. Palaeontographial Society Monograph 20(86), 177-214.

SHAw, F.C. 2000. Trilobites of the Králův Dvůr Formation (Ordovician) of the Prague Basin, Czech Republic. Věstník Českého geologického ústavu 75(4), 371-404.

ŠNAJDR, M. 1957. Klasifikace čeledě Illaenidae (Hawle a Corda) v českém starším paleozoiku. Sborník Ústředního ústavu geologického, Oddíl paleontologický 23, 125-284.

ŠNAJDR, M. 1958. Zbirovia vaneki nov. sp., nový trilobit z českého ordoviku. Sborník Ústredního ústavu geologického, Oddíl paleontologický 24, 207-215.

ŠNAJDR, M. 1990. Bohemian Trilobites. 265 pp. Ústrední Ústav Geologický, Prague.

Thadeu, D. 1947. Trilobites do Silúrico de Loredo (Buçaco). Boletim da Sociedade Geológica de Portugal 6(3), 217-236.

Troedsson, G.T. 1924. Remarks on the ontogeny of Illaenus. Geologiska Föreningens $i$ Stockholm Förhandlingar 46(3-4), 215-224. DOI 10.1080/11035892409442362
VANĚK, J. \& VALÍČEK, J. 2001. New index of the genera, subgenera, and species of Barrandian trilobites. Part A-B (Cambrian and Ordovician). Palaeontologia Bohemiae 7, 1-49.

VANĚK, J. \& VALíČEK, J. 2006. Supplements and corrections of New index of the genera, subgenera, and species of Barrandian trilobites (Vaněk et Valíček, 2001, 2002). Palaeontologia Bohemiae 10, 24-34.

VANĚK, J. \& VoKÁČ, V. 1997. Trilobites of the Bohdalec Formation (Upper Berounian, Ordovician, Prague Basin, Czech Republic). Palaeontologia Bohemiae 3, 20-50.

Whittington, H.B. 1954. Ordovician trilobites from Silliman's Fossil Mount. Geological Society of America Memoir 62, 119-149. DOI 10.1017/S0022336000035812

Whittington, H.B. 1997. Illaenidae (Trilobita): morphology of thorax, classification, and mode of life. Journal of Paleontology 71(5), 878-896.

Young, T.P. 1985. The stratigraphy of the Upper Ordovician of central Portugal. 441 pp. Ph.D. thesis, University of Sheffield, Sheffield, United Kingdom.

YounG, T.P. 1988. The lithostratigraphy of the Upper Ordovician of central Portugal. Journal of the Geological Society 145, 377-392. DOI 10.1144/gsjgs.145.3.0377

Zamora, S., Colmenar, J. \& Ausich, W.I. 2014. The echinoderm faunas from the Fombuena Formation (Upper Ordovician, Iberian Chains, Spain), 257-259. In Royo-Torres, R., Verdú, F.J. \& AlCalÁ, L. (eds) XXX Jornadas de Paleontología de la Sociedad Española de Paleontología. Fundamental! 24. 